\title{
Importance of dissolved organic nitrogen in the north Atlantic Ocean in sustaining primary production: a 3-D modelling approach
}

\author{
G. Charria ${ }^{1,2}$, I. Dadou ${ }^{1}$, J. Llido ${ }^{1,3}$, M. Drévillon ${ }^{1,4}$, and V. Garçon ${ }^{1}$ \\ ${ }^{1}$ Laboratoire d'Etudes en Géophysique et Océanographie Spatiales, UMR5566/CNRS/UPS, Toulouse, France \\ ${ }^{2}$ National Oceanography Centre, Southampton, UK \\ ${ }^{3}$ Institute for Marine and Atmospheric research Utrecht (IMAU), Utrecht, The Netherlands \\ ${ }^{4}$ European Centre for Research and Advanced Training in Scientific Computation, Toulouse, France
}

Received: 17 March 2008 - Published in Biogeosciences Discuss.: 17 April 2008

Revised: 1 September 2008 - Accepted: 1 September 2008 - Published: 27 October 2008

\begin{abstract}
An eddy-permitting coupled ecosystemcirculation model including dissolved organic matter is used to estimate the dissolved organic nitrogen (DON) supply sustaining primary production in the subtropical north Atlantic Ocean.

After an analysis of the coupled model performances compared to the data, a sensitivity study demonstrates the strong impact of parameter values linked to the hydrolysis of particulate organic nitrogen and remineralisation of dissolved organic nitrogen on surface biogeochemical concentrations.

The physical transport of dissolved organic nitrogen contributes to maintain the level of primary production in this subtropical gyre. It is dominated by the meridional component. We estimate a meridional net input of $0.039 \mathrm{molN} \mathrm{m}^{-2} \mathrm{yr}^{-1}$ over the domain $\left(13-35^{\circ} \mathrm{N}\right.$ and $71-$ $40^{\circ} \mathrm{W}$ ) in the subtropical gyre. This supply is driven by the Ekman transport in the southern part and by non-Ekman transport (meridional current components, eddies, meanders and fronts) in the northern part of the subtropical gyre. At $12^{\circ} \mathrm{N}$, our estimate $\left(18 \mathrm{kmolN} \mathrm{s}^{-1}\right)$ confirms the estimation $\left(17.9 \mathrm{kmolN} \mathrm{s}^{-1}\right)$ made by Roussenov et al. (2006) using a simplified biogeochemical model in a large scale model. This DON meridional input is within the range (from 0.05 up to $0.24 \mathrm{molN} \mathrm{m}^{-2} \mathrm{yr}^{-1}$ ) (McGillicuddy and Robinson, 1997; Oschlies, 2002) of all other possible mechanisms (mesoscale activity, nitrogen fixation, atmospheric deposition) fuelling primary production in the subtropical gyre. The present study confirms that the lateral supply of dissolved organic nitrogen might be important in closing the $\mathrm{N}$ budget over the north Atlantic Ocean and quantifies the importance of meridional input of dissolved organic nitrogen.
\end{abstract}

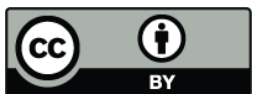

Correspondence to: G. Charria (guillaume.charria@legos.obs-mip.fr)

\section{Introduction}

The subtropical gyres cover large regions of the ocean $(40 \%$ of the global ocean, McClain et al., 2004). They represent a significant contribution to the biological pump of carbon in the global ocean estimated around 50\% (Emerson et al., 1997). The North Atlantic subtropical gyre is an example of these oligotrophic areas where inorganic nutrients concentrations are depleted and where the primary production (about $100 \mathrm{gC} \mathrm{m}^{-2} \mathrm{yr}^{-1}$ or $1.26 \mathrm{molN} \mathrm{m}^{-2} \mathrm{yr}^{-1}$, Ducklow, 2003) in the first $100 \mathrm{~m}$ depth is moderate. Furthermore, even if this production is weak, the extension of the subtropical gyre is quite important for the entire north Atlantic Ocean and has expanded over the 1996-2003 period (+4\% per year - McClain et al., 2004). Thus, the total primary production $(\mathrm{gC})$ in the gyres could be important due to the large extension of the gyre even if the primary production $\left(\mathrm{gC} \mathrm{m}^{-2}\right)$ is low. Moreover, the contribution of the subtropical gyre due to an expansion of its surface in the total primary production amount is becoming larger (McClain et al., 2004). Several unknowns remain on the sources of nutrients to sustain the primary production in the subtropical gyres. For the north Atlantic Ocean, the following five main mechanisms could be at work: (1) Transport of nutrients by mesoscale activity (i.e. eddies, meanders, fronts) ranging from 0.05 to $0.24 \mathrm{molN} \mathrm{m}^{-2} \mathrm{yr}^{-1}$ (i.e. McGillicuddy and Robinson, 1997; Siegel et al., 1999; Oschlies, 2002), (2) Meridional Ekman transport of dissolved organic matter slowly remineralized from the enriched boundaries of the oligotrophic gyre (i.e. Williams and Follows, 1998; Roussenov et al., 2006), for example around $0.047 \mathrm{molN} \mathrm{m}^{-2} \mathrm{yr}^{-1}$ in the subtropical gyre (Mahaffey et al., 2004), (3) Transport of nutrients and dissolved organic matter from the coastal upwelling areas (i.e. Mauritanian

Published by Copernicus Publications on behalf of the European Geosciences Union. 
upwelling - Roussenov et al., 2006), (4) Biological fixation of $\mathrm{N}_{2}$ gas ranging from 0.025 to $0.07 \mathrm{molN} \mathrm{m}^{-2} \mathrm{yr}^{-1}$ (i.e. Gruber and Sarmiento, 1997; Hansell et al., 2004), (5) Atmospheric transport and deposition of reactive nitrogen around $0.01(0.007-0.019) \mathrm{molN} \mathrm{m}^{-2} \mathrm{yr}^{-1}$ (Duce et al., 2008). All these processes represent possible candidates for sustaining primary production in the north Atlantic Ocean subtropical gyre.

In the present study, we investigate the importance of dissolved organic matter for fuelling primary production, especially in the subtropical gyre of the north Atlantic Ocean. In particular, the different meridional transports (Ekman and non-Ekman) are examined using a coupled physical/biogeochemical model covering the north Atlantic Ocean. The following questions are addressed: How the dissolved organic nitrogen pool is maintained? What is the role of meridional dissolved organic transport to sustain primary production?

After a description of the coupled model and of the in situ and remotely sensed data used, a model/data comparison is presented, which emphasizes the strong and weak points of the modelled fields. Sensitivity experiments are then performed showing the central role of processes linked to the dissolved organic matter. In the last section, the mechanisms associated with this organic matter are assessed and compared with previous studies in the north Atlantic Ocean.

\section{Methodology}

\subsection{Coupled physical/biogeochemical model}

The physics and dynamics of the ocean circulation are simulated using the OPA numerical model (8.1 version, Madec et al., 1999) in a north Atlantic Ocean configuration referred to as MNATL. This model was initially developed within the CLIPPER project by Barnier et al. (2000) and Tréguier et al. (2001) and used by the operational oceanography project MERCATOR (Etienne and Benkiran, 2007; http://www.mercator-ocean.fr). The primitive equations are solved using hydrostatic and rigid lid approximations. The TKE turbulent closure scheme (Blanke and Delecluse, 1993) is applied to calculate the vertical mixing of momentum and tracers. The MNATL configuration is restricted to the north Atlantic Ocean from $20^{\circ} \mathrm{S}$ to $70^{\circ} \mathrm{N}$ and from $98.5^{\circ} \mathrm{W}$ to $20^{\circ} \mathrm{E}$. A restoring term to the Reynaud et al. (1998) climatology for temperature and salinity was introduced in the Gulf of Cadiz (Drillet et al., 2005). The horizontal grid is a Mercator projection: the horizontal resolution of $1 / 3^{\circ}$ is modulated by the cosine of the latitude (i.e. $30 \mathrm{~km}$ at $35^{\circ} \mathrm{N}$ ). The model has 43 z-levels on the vertical among which 20 are lying in the first $1000 \mathrm{~m}$ of the ocean. The levels are about $12 \mathrm{~m}$ apart in the upper ocean and $200 \mathrm{~m}$ apart below $1500 \mathrm{~m}$. The model is forced with the ECMWF daily ocean-atmosphere fluxes. The Sea Surface Temperature (SST) and Sea Surface
Salinity (SSS) are restored to the weekly Reynolds's analysis (Reynolds and Smith, 1994) and to seasonal Reynaud et al.'s (1998) climatology, respectively.

To keep the model as simple as possible and in the mean time capture essential biogeochemical features in the north Atlantic Ocean (i.e. the spring bloom, the regenerated production in the oligotrophic gyre), the chosen model is an extended Oschlies and Garçon (1999) version that explicitly resolves DON, as successfully applied in Huret et al. (2005) for simulations in an estuary (see Appendix A for details). It includes 5 state variables: Phytoplankton (P), Zooplankton (Z), Dissolved Inorganic Nitrogen (N), Detritus (D) and Dissolved Organic Nitrogen (DON) (Fig. 1). The modelled DON is the semi-labile DON. The refractory pool of DON and the labile DON are not considered in these simulations, because their turnover rates are too long (hundred of years) and too short (less than a day), respectively (Kirchman et al., 1993; Carlson and Ducklow, 1995). This biogeochemical model (see Huret et al., 2005, for a detailed description of the model) is coupled with the MNATL circulation model previously described. The MUSCL (Monotonic Upstream centred Scheme for Conservation Laws) advection scheme was used for the biogeochemical tracers (Estubier and Levy, 2000). With this scheme, the errors due to diffusion and dispersion, which result in unrealistic negative concentrations, are minimized.

The parameter values (Table 1) are deduced from Oschlies and Garçon (1999) and Huret et al. (2005). A preliminary sensitivity study and data comparison were performed and led to new values for phytoplankton exudation, remineralisation and hydrolysis rates (Charria, 2005). The adjusted values for these three parameters are within the range of possible values estimated from the literature in the subtropical gyre of the north Atlantic Ocean (i.e. Dadou et al., 2004; Salihoglu et al., 2008). In this nitrogen based model, all tracers concentrations are expressed in nitrogen units $\left(\mathrm{mmolN} \mathrm{m}^{-3}\right)$. A variable chlorophyll-to-nitrogen ratio was used following Hurtt and Armstrong (1996) to convert modelled phytoplankton in nitrogen units into chlorophyll concentrations using the formulation:

$$
\mathrm{Chl}=1.59 \cdot \chi \cdot \mathrm{P}
$$

with $\mathrm{P}$ for phytoplankton concentration in $\mathrm{mmolN} \mathrm{m}^{-3}, \mathrm{Chl}$ for chlorophyll concentration in $\mathrm{mgChl} \mathrm{m}^{-3}$ and 1.59 for the standard chlorophyll to nitrogen ratio. If growth is light limited, then $\mathrm{Ch} / \mathrm{N}=1.59 \cdot \chi_{\max }$ refers to maximum $\mathrm{Chl} / \mathrm{N}$ and we chose $\chi_{\max }$ equal to 1 which gives a $\mathrm{C} / \mathrm{Chl}_{\min }$ of $25 \mathrm{gC}(\mathrm{gChl})^{-1}$. If phytoplankton growth is nutrient limited (due to low DIN concentrations), we adjust $\chi$ downwards to make it equally limited by light and nutrients (as observed in laboratory experiments, Sakshaug et al., 1989). We neglect the effect of $\chi$ on the light profile and then light limitation of growth is a linear function of $\chi$. Therefore, $\chi$ is simply given by $\chi=$ nutrient limited growth rate/light limited growth rate. We choose to fix the upper limit for the $(\mathrm{C} / \mathrm{Chl})_{\max }$ equal to 160. 


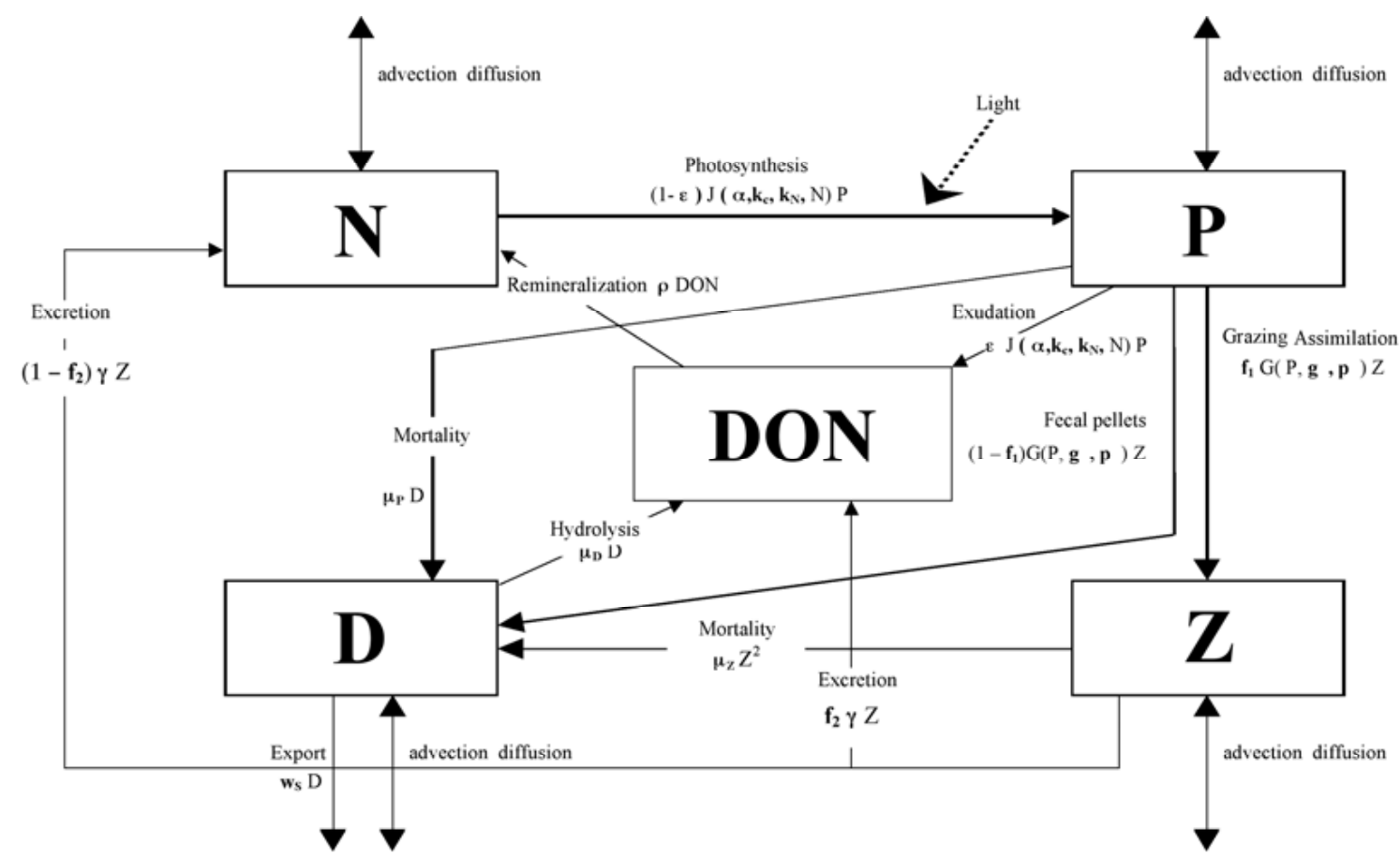

Fig. 1. The biogeochemical model from Huret et al. (2005).

Table 1. Parameters of the biogeochemical model.

\begin{tabular}{|c|c|c|c|c|}
\hline Parameter & Symbol & Value & Units & References \\
\hline Initial slope of P-I curve & $\alpha$ & 0.025 & $\left(\mathrm{~W} \mathrm{~m}^{-2}\right)^{-1} \mathrm{~d}^{-1}$ & OG99 \\
\hline Photosynthetically active radiation & PAR & 0.43 & - & OG99 \\
\hline Light attenuation coefficient of pure water & $k_{w}$ & 0.04 & $\mathrm{~m}^{-1}$ & OG99 \\
\hline Light attenuation coefficient of chlorophyll & $k_{c}$ & 0.03 & $\mathrm{~m}^{-1}\left(\mathrm{mmolN} \mathrm{m}^{-3}\right)^{-1}$ & OG99 \\
\hline \multirow[t]{3}{*}{ Maximum growth rate parameters } & $a$ & 0.6 & $\mathrm{~d}^{-1}$ & OG99 \\
\hline & $b$ & 1.066 & - & OG99 \\
\hline & $c$ & 1 & $\left({ }^{\circ} \mathrm{C}\right)^{-1}$ & OG99 \\
\hline Half saturation concentration for nutrient uptake & $K_{\mathrm{N}}$ & 0.5 & $\operatorname{mmolN~m}{ }^{-3}$ & OG99 \\
\hline Phytoplankton mortality rate & $\mu_{\mathrm{P}}$ & 0.03 & $d^{-1}$ & OG99 \\
\hline Phytoplankton exudation rate & $\varepsilon$ & 0.01 & - & $\mathrm{C} 05$ \\
\hline Assimilation efficiency of zooplankton & $f_{1}$ & 0.75 & - & H05 \\
\hline Maximum zooplankton grazing rate & $g$ & 2 & $d^{-1}$ & OG99 \\
\hline Zooplankton capture rate & $p$ & 1 & $\left(\mathrm{mmolN} \mathrm{m}^{-3}\right)^{-2} \mathrm{~d}^{-1}$ & OG99 \\
\hline (Quadratic) zooplankton mortality & $\mu_{\mathrm{Z}}$ & 0.2 & $\left(\mathrm{mmolN} \mathrm{m} \mathrm{m}^{-3}\right)^{-1} \mathrm{~d}^{-1}$ & OG99 \\
\hline Zooplankton excretion rate & $\gamma$ & 0.03 & $d^{-1}$ & OG99 \\
\hline Organic fraction of excretion & $f_{2}$ & 0.25 & - & H05 \\
\hline Hydrolysis rate of detritus & $\mu_{\mathrm{D}}$ & 0.23 & $d^{-1}$ & $\mathrm{C} 05$ \\
\hline Sinking velocity & $w_{S}$ & 5 & $\mathrm{md}^{-1}$ & OG99 \\
\hline Remineralization rate & $\rho$ & 0.025 & $d^{-1}$ & $\mathrm{C} 05$ \\
\hline
\end{tabular}

OG99: Oschlies and Garon (1999); H05: Huret et al. (2005); C05: Charria (2005). 


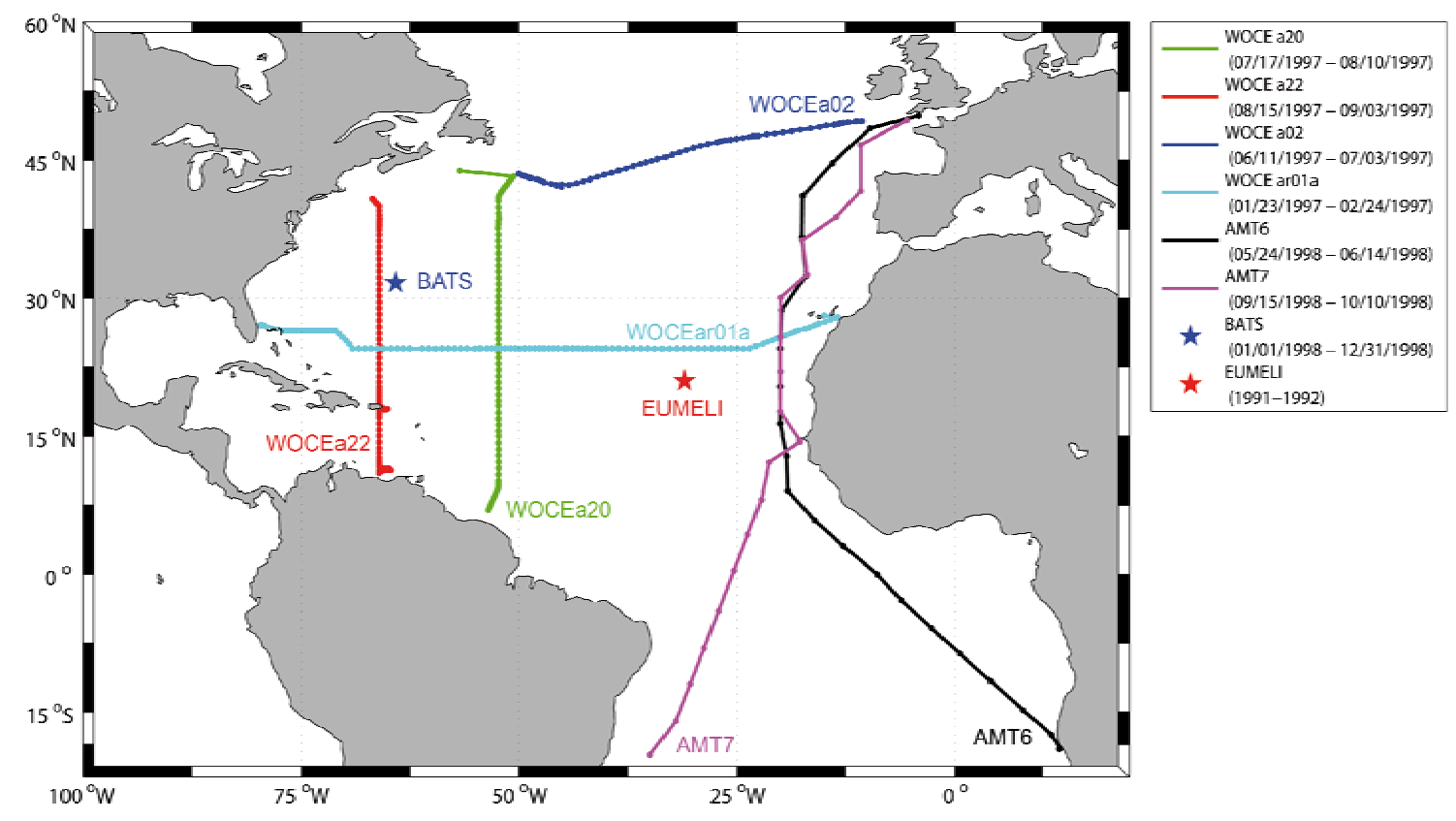

Fig. 2. Sections and stations used for the model/data comparison (latitude, longitude, time period and data).

The interannual simulation is initialized in temperature and salinity from the Reynaud et al.'s (1998) climatology for the circulation model. Initial conditions for dissolved inorganic nitrogen are taken from the nitrate climatology of Conkright et al. (1998). The other biogeochemical state variables are initialized to fixed values in space (longitude and latitude) as in Sarmiento et al. (1993) and Oschlies and Garçon (1999). The initial conditions for P, Z, DON are $0.14 \mathrm{mmolN} \mathrm{m}^{-3}, 0.014 \mathrm{mmolN} \mathrm{m}^{-3}$ and $3 \mathrm{mmolN} \mathrm{m}^{-3}$ at the surface, respectively, decreasing exponentially with a scale depth of $100 \mathrm{~m}$. The value of surface DON was deduced from the mean value calculated with the available data used (see the following Sect. 2.2). D is initialized with a small value everywhere $\left(10^{-4} \mathrm{mmolN} \mathrm{m}^{-3}\right)$. The physical model alone has been integrated since 1 January 1995. After one year of integration, the coupled model has been integrated for two years (1996-1997). After this two years spinup, the third year (from 1 January 1998) is analyzed. The biogeochemical fields are then spun-up with an established seasonal cycle.

\subsection{Data used}

Different data types have been used to compare with the model fields: satellite data, cruise sections through the north Atlantic basin as well as in situ data at moored stations. We focus on 1998 when all types of data previously listed are available except for WOCE (World Ocean Circulation Experiment) sections and EUMELI station (Fig. 2). We use the WOCE sections for the year 1997 as the physical structures are well simulated and the nitrate concentrations do not seem to change significantly between mid-1997 and 1998. Satellite chlorophyll- $a$ concentrations from monthly SeaWiFS products of level 3 binned data $(9 \times 9 \mathrm{~km}$, version 4 , O'Reilly et al., 2000) and in situ chlorophyll data (Ducklow, 2003) are compared to modelled chlorophyll concentrations on the first vertical level $(6 \mathrm{~m})$ of the model. Integrated modelled primary production over the euphotic zone is also assessed using primary production estimations from SeaWiFS data and three bio-optical models (Carr et al., 2006). Along WOCE (end of 1997) and AMT (Atlantic Meridional Transect) sections (in 1998) (Aiken and Bale, 2000), temperature $(T)$, salinity $(S)$, nitrates $\left(\mathrm{NO}_{3}\right)$ and chlorophyll $(\mathrm{Chl})$ concentrations are compared with model outputs for the same locations and periods. At BATS (Bermuda Atlantic Time-series Study) station $\left(31^{\circ} 40^{\prime} \mathrm{N}, 64^{\circ} 10^{\prime} \mathrm{W}\right)$ on the western part of the basin (e.g. Steinberg et al., 2001), an exhaustive comparison is performed between the available data and model fields for $T, S, \mathrm{NO}_{3}$, Chl, and dissolved organic nitrogen (DON). On the eastern part of the basin, the oligotrophic EUMELI (France-JGOFS EUtrophic, MEsotrophic and oLIgotrophic program) station data for the years 1991 and 1992 (Morel et al., 1996) have been put altogether to create a combined year with which the model fields are compared.

Statistical metrics are selected in order to compare model fields and data: the mean $(M)$, the bias $\left(M_{\text {model }}-M_{\text {data }}\right)$, the root mean square (RMS), the centred pattern RMS difference $\left(E^{\prime}=\sqrt{ }\left(\mathrm{RMS}^{2}-\right.\right.$ bias $\left.\left.^{2}\right)\right)$, the standard deviation $(\sigma)$ and the correlation $(R)$. Taylor's diagrams (Taylor, 2001) are used in order to summarize the statistical information $\left(\sigma, R, E^{\prime}\right)$. 


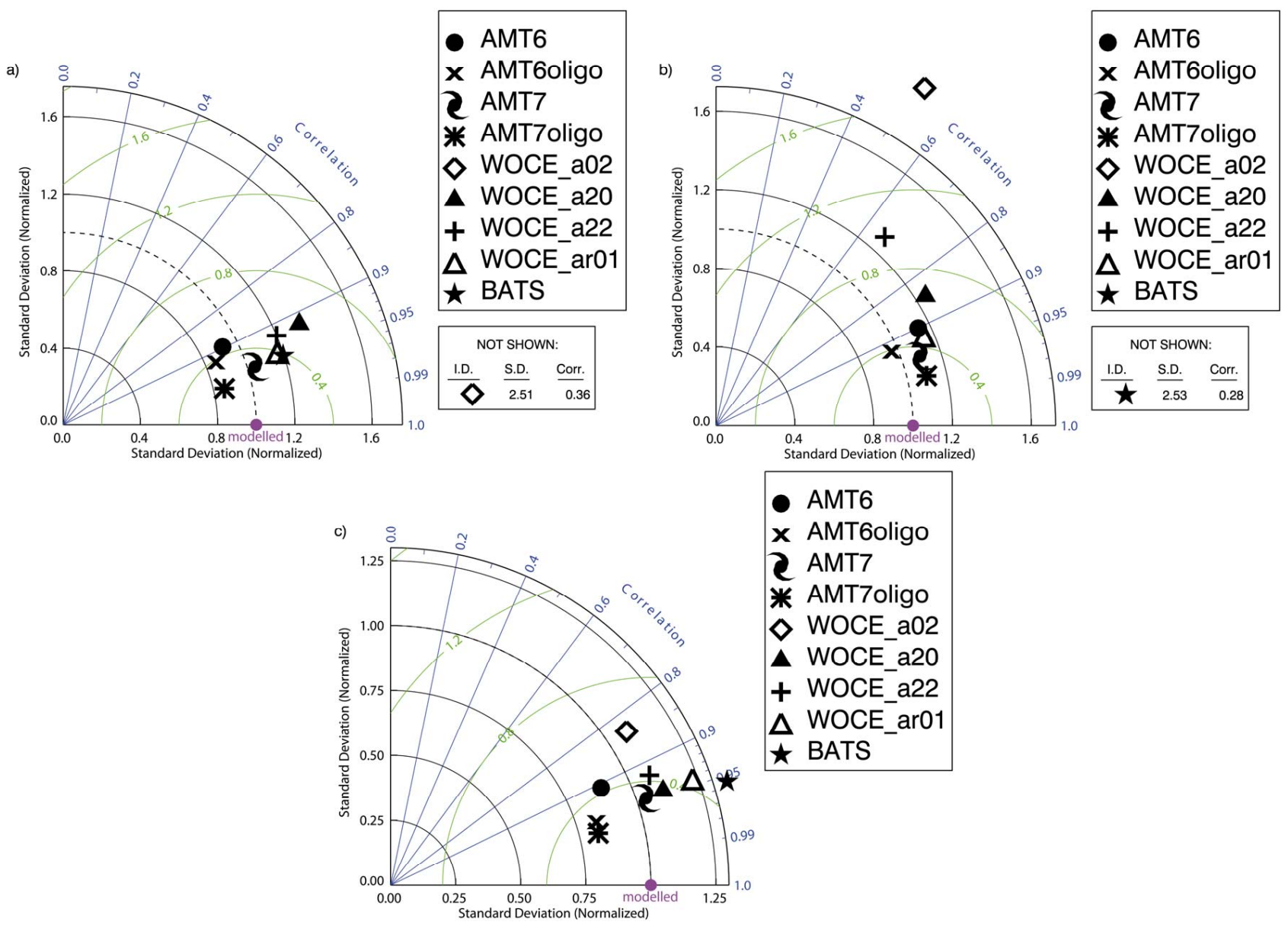

Fig. 3. Model performance analyses using Taylor's diagrams for (a) Temperature, (b) Salinity and (c) Density. The radial distance from the origin is proportional to the standard deviation of a pattern (normalised by the modelled standard deviation). The green lines measure the distance from the reference point and indicate the RMS error (once any overall bias has been removed; see the mathematical expression in Sect. 2.2). The correlation between the two fields is given by the azimuthal position of the test field. In the external rectangle, I.D., S.D., Corr. stand for the Symbol Identifier, the Standard Deviation and the Correlation, respectively. As it is mentioned in Sect. 3, the statistical metrics were computed following the available data for each dataset (vertical sections, time series or surface fields). Abbreviations used are: AMT6-AMT6 section (MayJune 1998), AMT6 oligo-AMT6 section only in the oligotrophic gyre, AMT7-AMT7 section (September-October 1998), AMT7 oligo-AMT7 section only in the oligotrophic gyre, BATS-Bermuda Atlantic Time-series Study (January-December 1998), WOCE_a02-WOCE section a02 (June-July 1997), WOCE_a20-WOCE section a20 (July-August 1997), WOCE_a22WOCE section a22 (August-September 1997), WOCE_ar01-WOCE section ar01 (January-February 1998).

\section{Model-data comparisons}

\subsection{Temperature, salinity, and density}

Along the WOCE sections, the difference between model and data averages (along the section and over the first $500 \mathrm{~m}$ depth) for temperature and salinity are from $-0.26^{\circ} \mathrm{C}$ to $-0.65^{\circ} \mathrm{C}$ and from -0.008 to -0.12 , respectively. For the AMT sections over the oligotrophic gyre, the difference between model and data averages (along the section and over the first $200 \mathrm{~m}$ depth) are from $-0.13^{\circ} \mathrm{C}$ to $-1.015^{\circ} \mathrm{C}$; from -0.18 to -0.185 . At BATS station, the differences between model and data averages (for the year 1998 and over the first $300 \mathrm{~m}$ depth) are equal to $-0.61{ }^{\circ} \mathrm{C}$ and -0.15 . In general, the modelled mean temperature and salinity is thus usually colder and fresher, respectively, than the observation mean. The standard deviation is also usually higher for the observed fields compared to the simulated fields (Fig. 3). The model spatial resolution of $1 / 3^{\circ}$ is too coarse to reproduce the highly variable small-scale processes. The correlation coefficient 

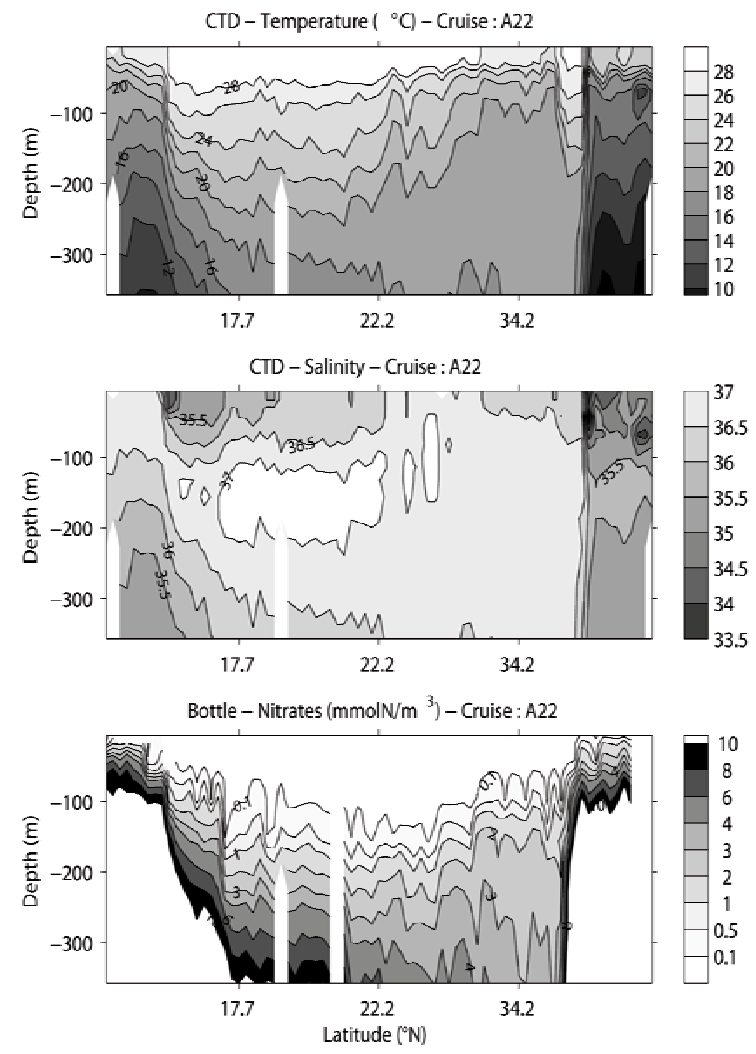
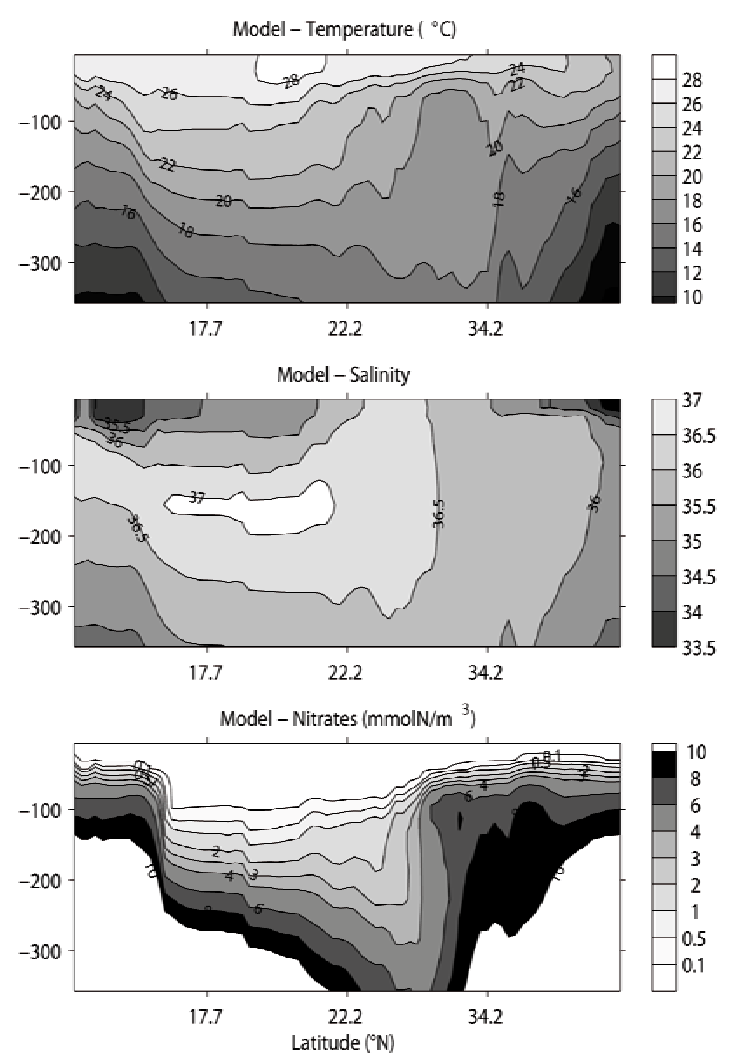

Fig. 4. Temperature (top), Salinity (middle), and Nitrates (bottom) measured along the WOCE A22 transect (left) and estimated with the coupled model (right) for the first $350 \mathrm{~m}$ depth.

for temperature $(T)$ between simulated and observed fields is above 0.9 for BATS station and all sections except for the A02 WOCE section (Fig. 3a). The normalized centred pattern RMS difference for $T$ is less than 0.5 (less than $2.2^{\circ} \mathrm{C}$ ) except for two WOCE sections (A20 and A02). For the salinity $(S)$ field, a clear distinction can be seen between the sections/station on the western part of the basin or near $40^{\circ} \mathrm{N}$ compared to the sections on the eastern part of the basin or at other latitudes. For the latter, the correlation coefficient between simulated and observed fields is above 0.9 ; the standard deviation of the modelled and observed fields is similar and the normalized centred pattern RMS difference is less than 0.5 (less than 0.23). On the western part of the basin, the statistics show a weaker agreement with observations and particularly, with the extreme case of the BATS station (Fig. 3b). The simulated density field is comparable to the observed one along the sections and at BATS station due to the compensation in density of the discrepancies in $T$ and $S$ (Fig. 3c).

As an example, simulated and observed distributions of $T$ and $S$ over the $350 \mathrm{~m}$ depth along the A22 WOCE section (North-South direction around 66 $\mathrm{W}$ in August 1997 - Fig. 2) are displayed in Fig. 4. This meridian section crosses the subtropical gyre on its western part which is well identified by warm (up to $28^{\circ} \mathrm{C}$ ) and salty (up to 37) waters between $13.2^{\circ} \mathrm{N}$ and $39^{\circ} \mathrm{N}$ in the observed and simulated fields (Fig. 4) above the first $200 \mathrm{~m}$. Below $200 \mathrm{~m}$, the North Atlantic Central Waters (NACW) (with $T$ near $20^{\circ} \mathrm{C}$ and $S$ near 36.7) between $39^{\circ} \mathrm{N}$ and $13.2^{\circ} \mathrm{N}$ can be identified. In the observed fields, colder and fresher water is found north of $39^{\circ} \mathrm{N}$, characterizing the Slope Water, north of the Gulf Stream current. In the simulated fields, these waters are found north of $41^{\circ} \mathrm{N}$. In our $1 / 3^{\circ}$ of resolution with zvertical coordinate configuration, the northern position of the Gulf Stream current is a well-known bias (e.g. Barnier et al., 2006). The temperature and salinity gradients in the simulated fields are weaker than in the observed fields. The simulated sea surface temperature in the subtropical gyre is colder than the observed SST. A detailed analysis of the North Atlantic Subtropical Mode Water (STMW - characterized by a subsurface thermostad centred roughly at $18^{\circ} \mathrm{C}$ ) between 150 and $400 \mathrm{~m}$ at different stations along this A22 section shows that the STMW is not well reproduced in the simulated fields (not shown). This bias is linked to the northern position of the modelled Gulf Stream current compared to the observations, because this mode water is formed south of this current (Palter et al., 2005). 

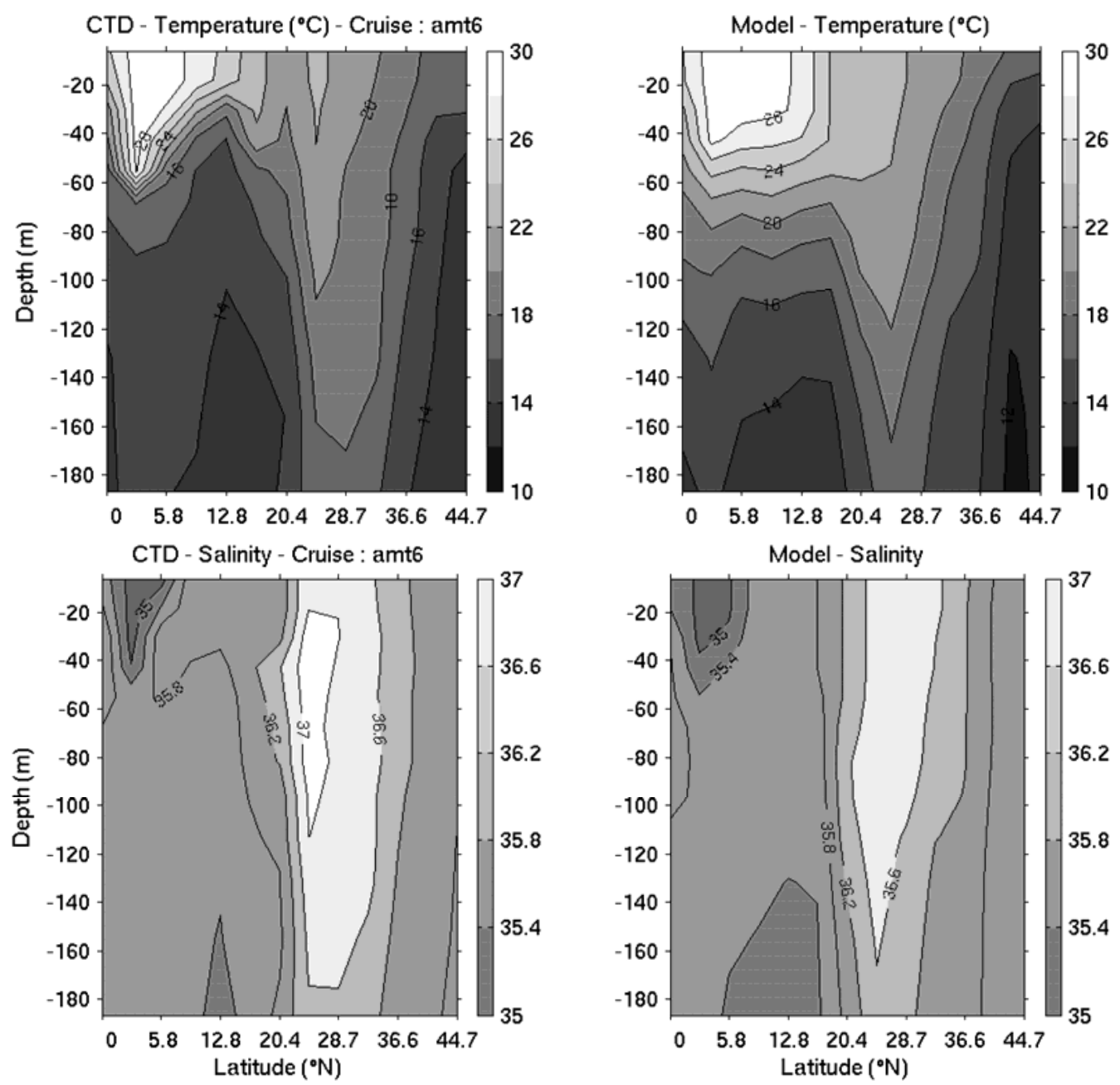

Fig. 5.1. Temperature (top) and Salinity (bottom) measured along the AMT6 transect (left) and estimated with the coupled model (right) for the first $200 \mathrm{~m}$ depth in May-June 1998.

Along the AMT 6 section (from 24 May 1998 to 14 June 1998) between $0^{\circ} \mathrm{N}$ and $50^{\circ} \mathrm{N}$ in the eastern part of the north Atlantic basin (see Fig. 2), the subtropical gyre waters are well represented in the coupled model compared to the observations. We only notice an underestimation of the Mauritanian upwelling and salinity values (no subsurface subtropical salinity maximum at 37) (Fig. 5.1). On the Equator, we can notice fresher waters associated with the Amazon River discharge waters. Indeed, these waters are advected eastward by the North Equatorial Counter Current and mixed with the equatorial upwelling waters (Aiken and Bale, 2000). They are well reproduced in the simulated salinity fields.

The model is able to reproduce the large-scale features of the temperature, salinity and density fields; however the modelled fields are generally fresher and colder than the observations.

\subsection{Nitrate and chlorophyll concentrations}

In this section, the nitrate and chlorophyll concentrations are averaged over the corresponding vertical sections (WOCE and AMT) or over the corresponding time series (BATS and EUMELI).

The modelled mean nitrate and chlorophyll concentrations are higher than the observation mean over the WOCE sections $\left(0.57 \mathrm{mmolN} \mathrm{m}^{-3} \leq\left[\mathrm{NO}_{3}\right]_{\text {model }}-\left[\mathrm{NO}_{3}\right]_{\text {data }} \leq\right.$ $0.7 \mathrm{mmolN} \mathrm{m}^{-3}$ ), the AMT sections $\left(\left[\mathrm{NO}_{3}\right]_{\text {model }}-\left[\mathrm{NO}_{3}\right]_{\text {data }}=1.5 \mathrm{mmolN} \mathrm{m}^{-3} ; 0.034 \mathrm{mgChl} \mathrm{m}^{-3}\right.$ $\left.\leq[\mathrm{Chl}]_{\text {model }}-[\mathrm{Chl}]_{\text {data }} \leq 0.096 \mathrm{mgChl} \mathrm{m}^{-3}\right)$ and at BATS station $\left(\left[\mathrm{NO}_{3}\right]_{\text {model }}-\left[\mathrm{NO}_{3}\right]_{\text {data }}=4.4 \mathrm{mmolN} \mathrm{m}^{-3}\right.$; $\left.[\mathrm{Chl}]_{\text {model }}-[\mathrm{Chl}]_{\mathrm{data}}+0.13 \mathrm{mgChl} \mathrm{m}^{-3}\right)$. The highest mean bias is obtained at BATS in agreement with the bad representation of the thermohaline waters properties in this area as mentioned above. We also compare the model outputs with the observations at the EUMELI site. Even 

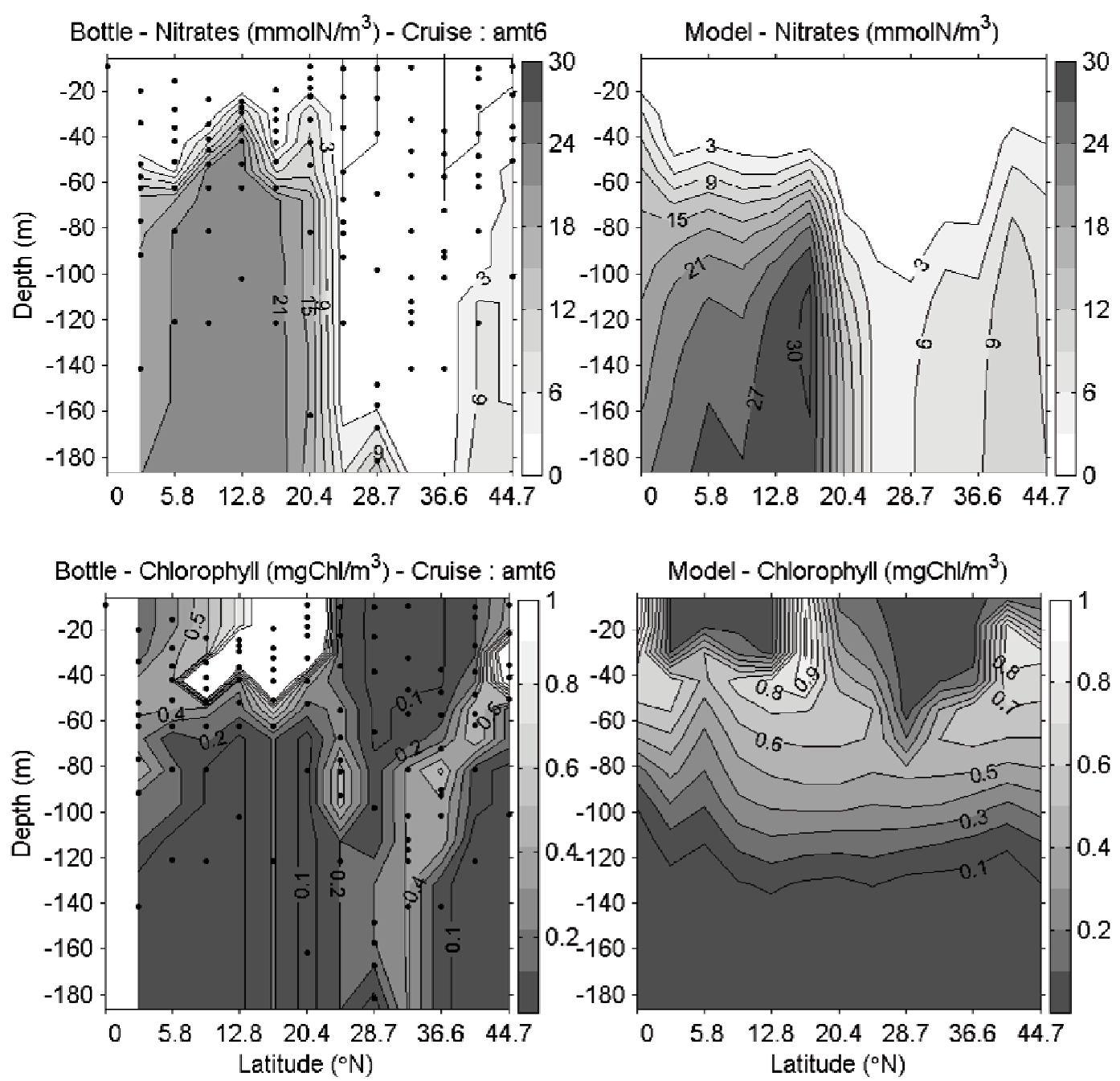

Fig. 5.2. Nitrates (top) and Chlorophyll (bottom) measured along the AMT6 transect and estimated with the coupled model (right) for the first $200 \mathrm{~m}$ depth in May-June 1998.

if the period of the EUMELI survey (1991-1992) is not the same than the simulated year (1998) (see Sect. 2.2), this site is considered due to its location within the oligotrophic waters. For this site $\left(21^{\circ} \mathrm{N}, 31^{\circ} \mathrm{W}\right)$, the simulated nutrient mean concentration over the year 1998 is higher than the observed nitrate mean over the years 1991-1992 $\left(\left[\mathrm{NO}_{3}\right]_{\text {model }}-\left[\mathrm{NO}_{3}\right]_{\text {data }}=1.22 \mathrm{mmolN} \mathrm{m}{ }^{-3}\right)$ and simulated chlorophyll concentrations are slightly underestimated $\left([\mathrm{Chl}]_{\text {model }}-[\mathrm{Chl}]_{\text {data }}=-0.08 \mathrm{mgChl} \mathrm{m}^{-3}\right)$.

The standard deviation is also higher at EUMELI for the observed fields as compared to the simulated fields even if this difference is not as clear as for the T and S fields (Fig. 6).

The correlation coefficient for nutrients between simulated and observed fields range between 0.35 and 0.9 ; a higher correlation is obtained for the eastern part of the north Atlantic Ocean (Fig. 6a). The correlation for the chlorophyll concentrations is weaker (less than 0.4) (Fig. 6b). It is mainly due to a different vertical chlorophyll distribution as simulated by the model with shallower subsurface maximum and higher amplitude of the annual chlorophyll cycle in the oligotrophic gyre (not shown here).

The normalized centred pattern RMS difference for nutrients and chlorophyll concentrations are between 0.4 and 1.2 (between 1 and $5.5 \mathrm{mmolN} \mathrm{m}^{-3}$ ) and between 1 and 1.6 (between 0.16 and $0.57 \mathrm{mgChl} \mathrm{m}^{-3}$ ) (Fig. 6).

Along the A22 WOCE section, the observed nitrate concentrations are very low in the waters of the subtropical oligotrophic gyre between $13.17^{\circ} \mathrm{N}$ and $39^{\circ} \mathrm{N}$. These concentrations are rather well simulated by the model except the vertical gradients, which are smoother than in the observations (Fig. 4).

For the AMT6 section, the simulated nitrate field structures compare well with the observed structures except the northern border of the oligotrophic gyre, which has a too southern position as compared to the data (Fig. 5.2). For example, at $36.6^{\circ} \mathrm{N}$, the observed nitrate concentrations are 
less than $5 \mathrm{mmolN} \mathrm{m}{ }^{-3}$ whereas the simulated dissolved inorganic nitrogen concentrations are around $10 \mathrm{mmolN} \mathrm{m}^{-3}$. The enriched nitrate waters of the Mauritania upwelling (between $12.8^{\circ} \mathrm{N}$ and $20.4^{\circ} \mathrm{N}$ ) and of the Equatorial upwelling are well reproduced in the simulated fields. The chlorophyll concentrations at the southern and northern borders of the oligotrophic gyre are too high as compared to the observations (Fig. 5.2).

In this section, direct model-data comparisons were performed to identify the biases in the modelled physi$\mathrm{cal} / \mathrm{biogeochemical} \mathrm{fields.} \mathrm{We} \mathrm{kept} \mathrm{similar} \mathrm{locations} \mathrm{of} \mathrm{the}$ stations and sections in the simulated fields and the observations. For example, improved statistics would be obtained at BATS using a southern station in the model grid. However, a comparison at BATS coordinates gives more information about the discrepancies between model and observations. Finally, the model overestimates chlorophyll and dissolved inorganic nitrogen concentrations. However the seasonal annual cycle and the main patterns of the vertical structure are well reproduced.

3.3 Surface chlorophyll concentrations and primary production

After using in situ data (along sections and at fixed stations), the synoptic 9-km-resolution monthly SeaWiFS data have been used to compare chlorophyll concentrations in surface waters. Over the north Atlantic basin for the year 1998, the simulated chlorophyll concentrations are underestimated as compared to the data (mean over the basin: $[\mathrm{Chl}]_{\text {model }}-[\mathrm{Chl}]_{\text {data }}=-0.134 \mathrm{mgChl} \mathrm{m}^{-3}$ ), especially at high latitudes (Fig. 7). The correlation is very low (0.13) and the normalized centred pattern RMS difference is high $\left(0.98 \mathrm{mgChl} \mathrm{m}^{-3}\right)$ for the whole basin (Fig. 6b). These poor statistics can be explained examining the chlorophyll concentration distribution over the north Atlantic Ocean, for example for the spring bloom season (Fig. 7). First, the weakest latitudinal extension of the oligotrophic gyre strongly decreases the correlation between modelled and remotely sensed chlorophyll concentrations. Indeed, the northern border of the oligotrophic gyre as simulated by the model has a southernmost position as compared to the data. The reduced oligotrophic gyre extension in its northern boundary could be partly associated with the misrepresentation of the STMW, characterized by low dissolved inorganic nitrogen concentrations (Palter et al., 2005).

Secondly, in the northern part of the basin, the bloom has a patchy structure, which is difficult to reproduce. This patchiness of the bloom is partly due to small-scale physical processes, which are not solved in our model with a $1 / 3^{\circ}$ spatial resolution. Nevertheless, simulations present a good agreement with observations in magnitude. The spring bloom period is quite well represented in the simulated chlorophyll concentrations fields as well as the seasonal variability (not shown).

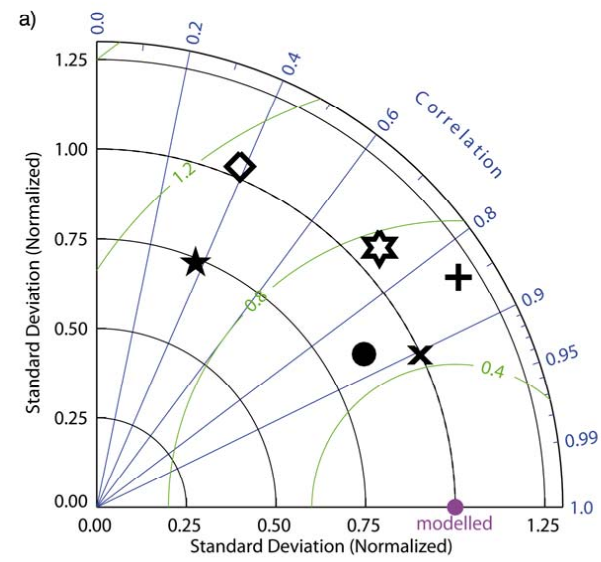

AMT6

X AMT6oligo

$\checkmark$ WOCE_a02

+ WOCE_a22

\ BATS

* EUMELI

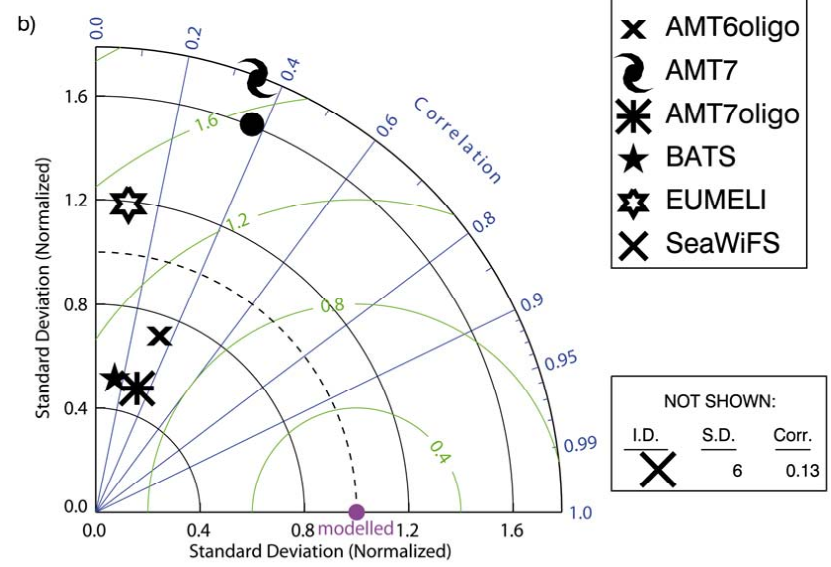

Fig. 6. Model performance analyses using Taylor's diagrams for (a) nitrates and (b) chlorophyll surface concentrations. EUMELI stands for EUMELI data (1991-1992) at $21^{\circ} \mathrm{N}$ and $31^{\circ} \mathrm{W}$. SeaWiFS stands for the year 1998 over the model domain. See the legend of Fig. 2 for details and other abbreviations.

Following the study by Ducklow (2003), in Table 2, we compare the integrated (over $112 \mathrm{~m}$ depth during the year 1998) simulated primary production (PP) with different estimations of PP from satellite data (based on 1979 to 1986 data in Longhurst et al., 1995; based on 1978 to 1986 data in Antoine and Morel, 1996; based on 1971 to 1994 measurements in Behrenfeld and Falkowski, 1997; based on 1998 to 2002 measurements in Mélin, 2003) over the different biogeochemical provinces defined by Longhurst (1998). For the polar region (Atlantic Artic Province - ARCT and Atlantic Subarctic Province - SARC) as well as in the North Atlantic Drift Province (NADR), the modelled PP (around $230 \mathrm{mgC} \mathrm{m}^{-2} \mathrm{~d}^{-1}$ ) is underestimated. PP is mainly limited by light at these latitudes. The simulated convection is higher in these provinces than the convection that 

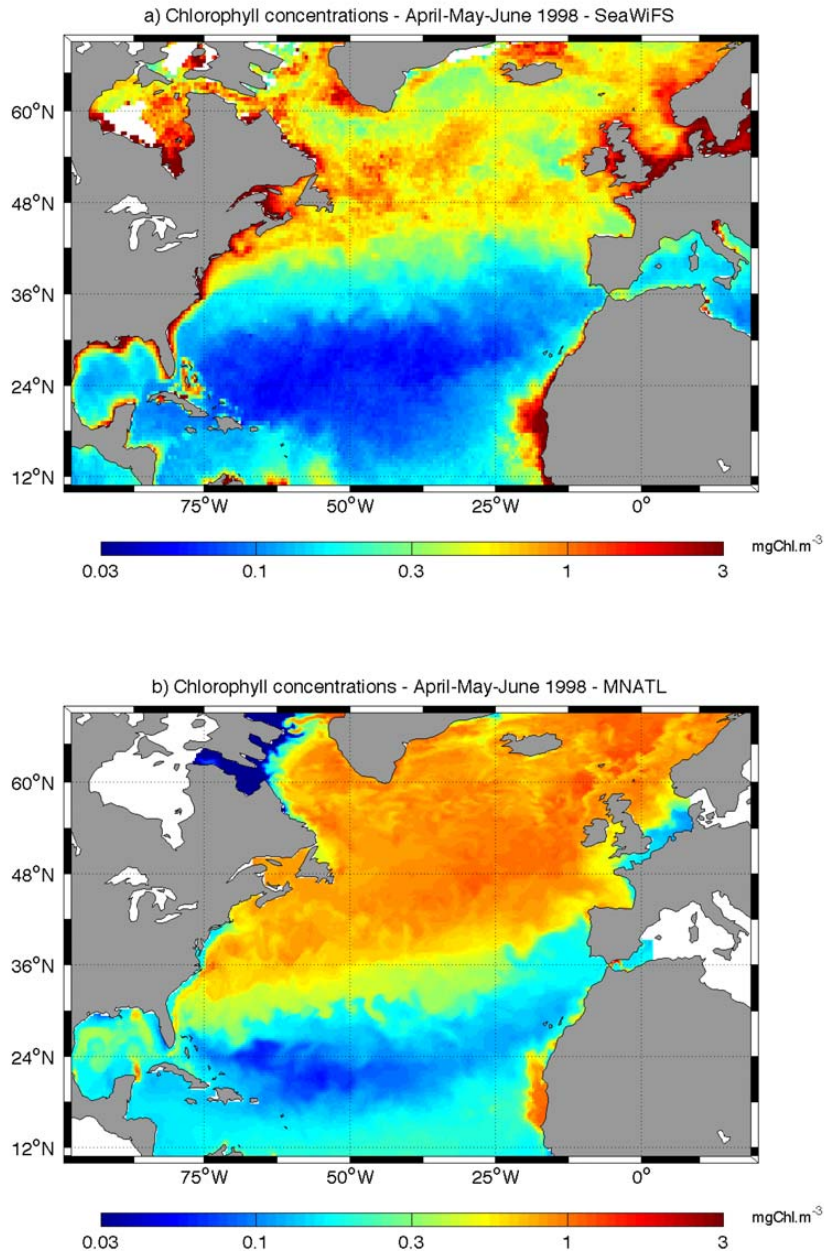

Fig. 7. Surface Chlorophyll concentration $\left(\mathrm{mgChl} \mathrm{m}^{-3}\right)$ averaged from April up to June 1998 with (a) SeaWiFS data and with (b) the coupled modelled fields.

can be estimated from the observations (e.g. Barnier et al., 2006), which partly explain this underestimation. Another explanation is that the model does not explicitly resolve the diurnal cycle, and the day light forcing could be improved using a higher frequency forcing (i.e. $6 \mathrm{~h}$ ). In the Gulf Stream province, the PP, equal to $363 \mathrm{mgC} \mathrm{m}^{-2} \mathrm{~d}^{-1}$, is also underestimated as compared with the satellite estimation (Table 2). This difference can be due to the coarse $1 / 3^{\circ}$ horizontal resolution of the model that does not allow to properly reproduce the most intense mesoscale processes commonly observed in this energetic region. In the North Atlantic Subtropical Gyral provinces (East - NASE and West - NASW), the modelled PP $\left(392 \mathrm{mgC} \mathrm{m}^{-2} \mathrm{~d}^{-1}\right.$ in the NASE and $448 \mathrm{mgC} \mathrm{m}^{-2} \mathrm{~d}^{-1}$ in the NASW) is in agreement with satellite estimates. In the last province (NATR), the modelled PP $\left(219 \mathrm{mgC} \mathrm{m}^{-2} \mathrm{~d}^{-1}\right)$ is slightly underestimated.
Table 2. Primary production $\left(\mathrm{mgC} \mathrm{m}^{-2} \mathrm{~d}^{-1}\right)$ estimated by different studies (this study, LON95 (Longhurst et al., 1995), ME (Mélin, 2003), AM96 (Antoine and Morel, 1996) and BF97 (Behrenfeld and Falkowski, 1997) for different biogeochemical provinces as defined by Longhurst (1998): ARCT (Atlantic Arctic Province), SARC (Atlantic Subarctic Province), NADR (North Atlantic Subtropical Drift Province), GFST (Gulf Stream province), NASW (North Atlantic Subtropical Gyral Province - West), NASE (North Atlantic Subtropical Gyral Province - East), NATR (North Atlantic Tropical Gyre Province). See Sect. 3.3 for details.

\begin{tabular}{lccccc}
\hline $\begin{array}{l}\text { Biogeochemical } \\
\text { provinces }\end{array}$ & LON95 & ME & AM96 & BF 97 & $\begin{array}{c}\text { This } \\
\text { study }\end{array}$ \\
\hline ARCT & 1330 & 507 & 430 & 687 & 173 \\
SARC & 830 & 472 & 483 & 887 & 249 \\
NADR & 660 & 555 & 484 & 852 & 230 \\
GFST & 490 & 522 & 488 & 677 & 363 \\
NASW & 260 & 304 & 355 & 360 & 448 \\
NASE & 330 & 410 & 413 & 526 & 392 \\
NATR & 290 & 313 & 513 & 363 & 219 \\
\hline
\end{tabular}

\subsection{Dissolved organic nitrogen concentrations}

The dissolved organic nitrogen (DON) concentrations (the semi-labile fraction here) is underestimated in the simulation as compared to the BATS data (the difference between model and data averages - same definition as in Sect. 3.1 - for the semi-labile DON is equal to $-0.75 \mathrm{mmolN} \mathrm{m}^{-3}$; Knapp et al., 2005; Salihoglu et al., 2008) and EUMELI station $\left(-1.45 \mathrm{mmolN} \mathrm{m}^{-3}\right.$; Pujo-Pay and Raimbault, 1994; Pujo-Pay, 1995). The semi-labile DON pool (Fig. 8a) is estimated by subtracting the refractory DON concentration (equal to $2.45 \mathrm{mmolN} \mathrm{m}^{-3}$ at BATS station, $3 \mathrm{mmolN} \mathrm{m}^{-3}$ at EUMELI station and $2.14 \mathrm{mmolN} \mathrm{m}^{-3}$ along the AMT10 section) from the total DON measurement. The standard deviations for the simulated DON (Fig. 8b) and DON data (Fig. 8a) are quite comparable at BATS station $\left(0.7\right.$ and $0.4 \mathrm{mmolN} \mathrm{m}^{-3}$, respectively). At EUMELI station, the standard deviation is lower in the simulation $\left(0.4 \mathrm{mmolN} \mathrm{m}^{-3}\right)$ as compared to the data $\left(1 \mathrm{mmolN} \mathrm{m}{ }^{-3}\right)$. At both stations, the correlation is low (less than 0.5 ) due to the vertical structure of the simulated profile of DON as compared with the in situ DON profile. We also qualitatively compared the simulated DON section with the AMT10 (April-June 2000) section for DON concentrations (Mahaffey et al., 2004; Roussenov et al., 2006). The range of concentrations is comparable, between 3 and $5 \mathrm{mmolN} \mathrm{m}^{-3}$ for the first $200 \mathrm{~m}$ depth. 

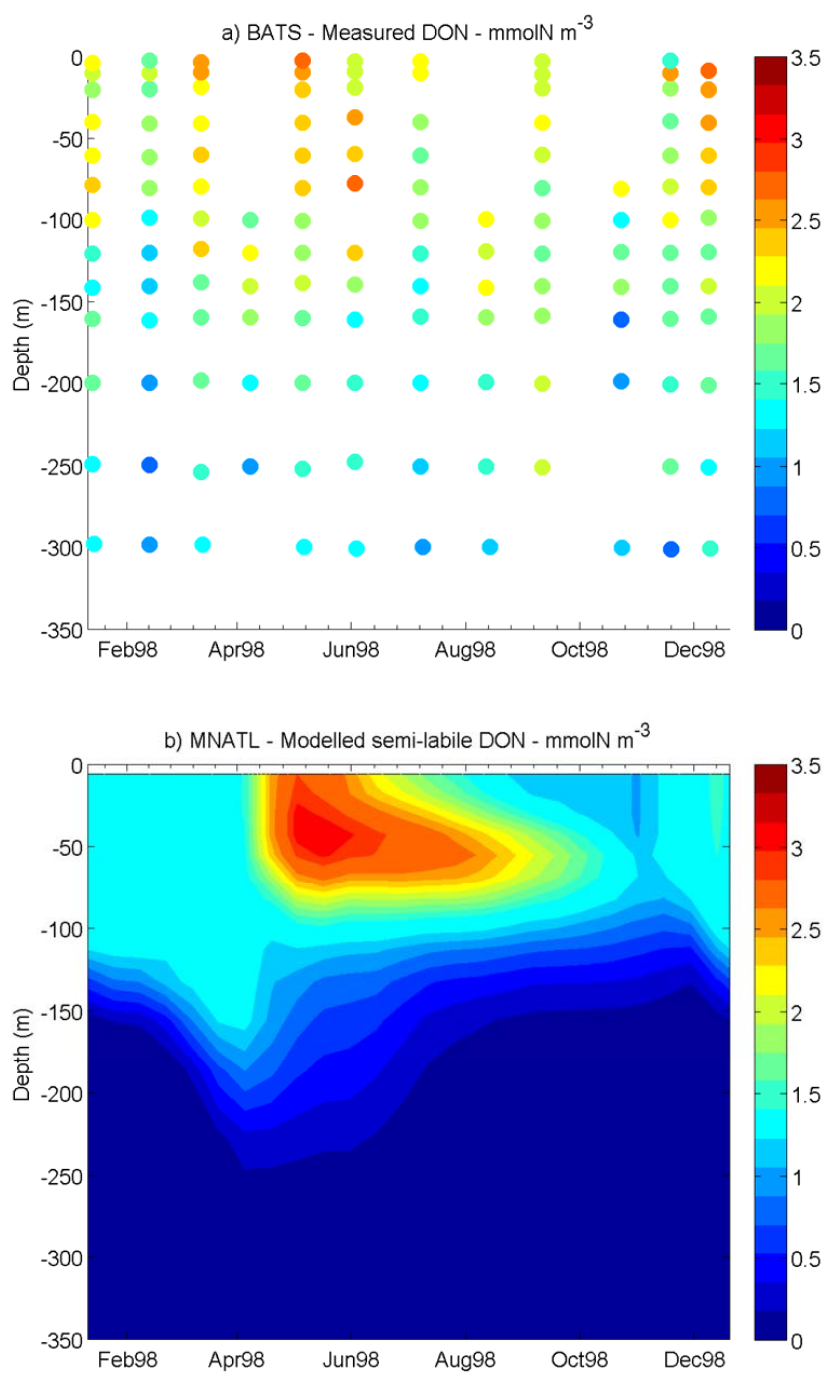

Fig. 8. Observed (a) and modelled (b) time series of dissolved organic nitrogen $\left(\mathrm{mmolN} \mathrm{m}^{-3}\right)$ at the BATS site $\left(31^{\circ} 40^{\prime} \mathrm{N}\right.$, $\left.64^{\circ} 10^{\prime} \mathrm{W}\right)$ in 1998.

Other cruises in 1995 (Vidal et al., 1999) and 1996 (Kähler and Koeve, 2001) have provided DON concentration observations for winter and summer seasons, respectively. These observations of total dissolved organic nitrogen (and not only semi-labile fraction) do not correspond to our simulated year 1998. Nevertheless, a qualitative comparison can be performed. In 1996, Kähler and Koeve (2001) measured DON along a section at $20^{\circ} \mathrm{W}$ between $35^{\circ} \mathrm{N}$ and $50^{\circ} \mathrm{N}$. Along this section, surface modelled DON concentrations are between 1 and $4 \mathrm{mmolN} \mathrm{m}^{-3}$ (weakest values are south of $40^{\circ} \mathrm{N}$ ). For the same location, observed concentrations are almost constant around $6 \mathrm{mmolN} \mathrm{m}^{-3}$ for the total DON. If we remove the refractory part $\left(5.5 \mathrm{mmolN} \mathrm{m}^{-3}\right) \mathrm{de}-$ duced from the deeper vertical profile presented in the paper, very low semi-labile DON values are comparable to

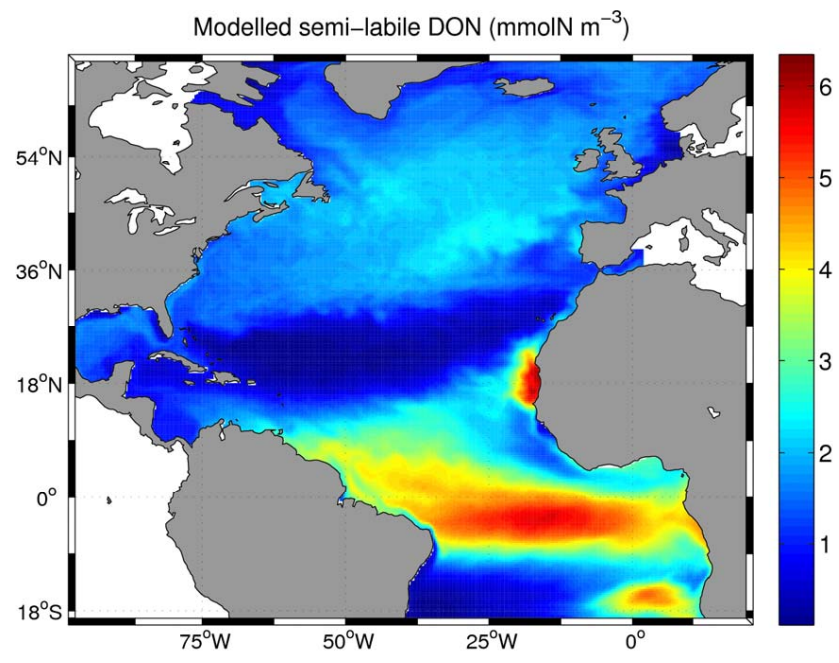

Fig. 9. Surface semi-labile dissolved organic nitrogen concentrations (mmolN m${ }^{-3}$ ) annually averaged in 1998 .

our minimum scale. The other observations from Vidal et al. (1999) in summer 1996 are highlighting large DON concentrations $\left(>7 \mathrm{mmolN} \mathrm{m}^{-3}\right.$ ) in the first $100 \mathrm{~m}$ depth with an increase close to the equator and around $20^{\circ} \mathrm{N}$. In the modelled fields, we observe similar increases with a maximum shifted north around $20^{\circ} \mathrm{N}$. An accurate estimation of the refractory pool is not given in this study but if the value for the AMT10 cruise is considered $\left(2.14 \mathrm{mmolN} \mathrm{m}^{-3}\right)$, the modelled maxima (between 4 and $5 \mathrm{mmolN} \mathrm{m}^{-3}$ ) are similar to those observed (between 4.86 and 8.86 mmolN $^{-3}$ ).

In Fig. 9, the annual distribution of surface semi-labile dissolved organic nitrogen concentrations presents the main biogeochemical features with smaller concentrations in the oligotrophic gyre $\left(<1 \mathrm{mmolN} \mathrm{m}^{-3}\right)$ and larger concentrations in the upwelling regions $\left(>5 \mathrm{mmolN} \mathrm{m}^{-3}\right.$ ) linked to upwelled deep waters with low DON but high DIN concentrations which enhance the DON production in surface waters. These structures are in agreement with biogeochemical model dynamics.

\section{Sensitivity studies for dissolved organic nitrogen}

In order to assess the DON role in the north Atlantic Ocean (especially in the oligotrophic gyre), we perform parameter sensitivity analyses on a pre-bloom/bloom/post-bloom period from Mid-March to Mid-July 1998. We arbitrarily change the parameter values of the microbial loop in the simple biogeochemical model. Parameters are modified one by one and their reference values are: divided by two $(-50 \%)$, multiplied by two $(+100 \%)$ and equal to a very small value, $10^{-4}(-100 \%)$ (Table 3). The model fields (DON, N, P, $\mathrm{Z}$ and $\mathrm{D}$ ) are evaluated following the different experiments. 
Table 3. Parameters values during sensitivity experiments for $\varepsilon, f_{2}, \gamma, \mu_{\mathrm{D}}, \rho$.

\begin{tabular}{lllll}
\hline Parameter & $\begin{array}{l}\text { Unper- } \\
\text { turbed }\end{array}$ & $+100 \%$ & $-50 \%$ & $-100 \%$ \\
\hline$\varepsilon$ & 0.01 & 0.02 & 0.005 & $10^{-4}$ \\
$f_{2}$ & 0.25 & 0.5 & 0.125 & $10^{-4}$ \\
$\gamma$ & $0.03 \mathrm{~d}^{-1}$ & $0.06 \mathrm{~d}^{-1}$ & $0.015 \mathrm{~d}^{-1}$ & $10^{-4} \mathrm{~d}^{-1}$ \\
$\mu_{\mathrm{D}}$ & $0.23 \mathrm{~d}^{-1}$ & $0.46 \mathrm{~d}^{-1}$ & $0.115 \mathrm{~d}^{-1}$ & $10^{-4} \mathrm{~d}^{-1}$ \\
$\rho$ & $0.025 \mathrm{~d}^{-1}$ & $0.05 \mathrm{~d}^{-1}$ & $0.0125 \mathrm{~d}^{-1}$ & $10^{-4} \mathrm{~d}^{-1}$ \\
\hline
\end{tabular}

The perturbed simulations are compared to the unperturbed simulation (referred as "modelled" fields in the previous and next sections). The results are summarized using Taylor's representation (Taylor, 2001).

This sensitivity study focuses on parameters related to the DON state variable. There are three sources of DON in the ecosystem model controlled by three parameters. First, a fraction of the phytoplankton exudation quantified by the $\varepsilon$ coefficient is increasing the DON concentration. Another source is the dissolved organic part of the zooplankton excretion. This flux depends on two parameters, the zooplankton excretion $(\gamma)$ and the dissolved organic fraction of this excretion $\left(f_{2}\right)$. Finally, DON can increase through the hydrolysis process creating DON from particulate organic nitrogen. This last process is controlled by the hydrolysis rate coefficient $\left(\mu_{\mathrm{D}}\right)$. The last parameter that we perturbed is the remineralization rate $(\rho)$, which represents the only DON sink in our model (Fig. 1).

Figure 10 shows the results of these different experiments in terms of sensitivity to the surface concentrations. If we consider the $\varepsilon$ parameter, it appears that it has a very weak influence on surface concentrations. The perturbed experiments have a strong correlation with the unperturbed run and a standard deviation very close to the unperturbed run. The maximum concentration differences are under $0.08 \mathrm{mmolN} \mathrm{m}^{-3}$ except for dissolved inorganic nitrogen in the Mauritanian upwelling, the subpolar gyre and the tropical regions where the differences reach $0.25 \mathrm{mmolN} \mathrm{m}^{-3}$ (not shown). The dissolved organic part of the zooplankton excretion flux, another source of DON, is driven by two parameters described above $\left(\gamma\right.$ and $f_{2}$ ). Through the sensitivity experiments, the fraction $f_{2}$ seems to have a weak effect on the N, Z, and DON concentrations (Fig. 10a, c and e). Correlations between sensitivity experiments and the reference simulation are high and standard deviations are similar. Surface concentration values remain almost unperturbed. At the opposite, the $\gamma$ coefficient has no marked effect on N, Z and DON concentrations but the correlation is decreased as compared to the reference phytoplankton concentrations (Fig. 10b). Correlations are high for the phy- toplankton concentrations, 0.99 , but weaker than those obtained by these parameter changes on other state variables concentrations. Furthermore, the standard deviation of phytoplankton distribution decreases (increases) when the fluxes from $\mathrm{Z}$ to $\mathrm{N}$ are decreasing (increasing) (Fig. 10b). It shows a sensitivity of the phytoplankton standard deviation to the loss of dissolved inorganic nitrogen.

These two sources from the $\mathrm{P}$ and $\mathrm{Z}$ pools of DON (phytoplankton exudation and zooplankton excretion) do not have an impact on DON surface concentrations even if these fluxes are almost cancelled (Fig. 10e).

Results are different concerning the last and main source: the hydrolysis of particulate organic nitrogen. When this flux is nearly removed, the correlation $(\sim 0.4)$ dramatically decreases between the sensitivity experiment and the reference simulation for the DON concentrations and the standard deviation is divided by more than two (Fig. 10e). If we look at the concentration distribution, the subpolar gyre becomes depleted in DON except the eastern part of the basin between $30^{\circ} \mathrm{N}$ and $40^{\circ} \mathrm{N}$. A similar impact is observed in the tropical latitudes. More generally, concentrations dramatically decrease in the simulated field. This effect is also important when the flux is divided by a factor two. The inverse process, with an increase of surface concentrations, is occurring when the flux is doubled. These results show that the hydrolysis is the main source of DON in our area. The effect on other surface concentrations is similar except for nitrates, which tend to be less sensitive to the DON concentration (Fig. 10a). It can be explained by the overturning time, which is around 4 days from $D$ to DON and around 40 days from DON to $\mathrm{N}$ in our simulation. We examine the sensitivity of the last component, sink of DON, and thus the concentrations sensitivity to the remineralization rate $(\rho)$. Even on this short time period (3.5 months), changes of the DON sink have a strong influence on surface concentrations. The main impact is observed on DON concentrations with a standard deviation very different from the unperturbed simulation (Fig. 10e). The decrease in DON surface concentration can reach $6 \mathrm{mmolN} \mathrm{m}^{-3}$ in the Mauritanian upwelling when the flux is stopped. Similar perturbations are observed on other state variables. For example, a strong effect can be noticed on phytoplankton concentrations in regions where the primary production is stronger (northern boundary of the subtropical gyre, Mauritanian upwelling and equator the Equator). In these regions, the concentration differences between the unperturbed and the perturbed simulations reach $0.6 \mathrm{mmolN} \mathrm{m}^{-3}$. Perturbations of the remineralization rate have also an impact on dissolved inorganic nitrogen concentrations even if dissolved inorganic nitrogen from DON is quickly consumed. This effect is not clear following the statistics on the Taylor diagram (Fig. 10a) but the concentration increase and decrease are important (between 1 and $3 \mathrm{mmolN} \mathrm{m}^{-3}$ ) in regions where nitrates concentrations are the highest (subpolar gyre, Mauritanian upwelling and the Equator) (not shown). 

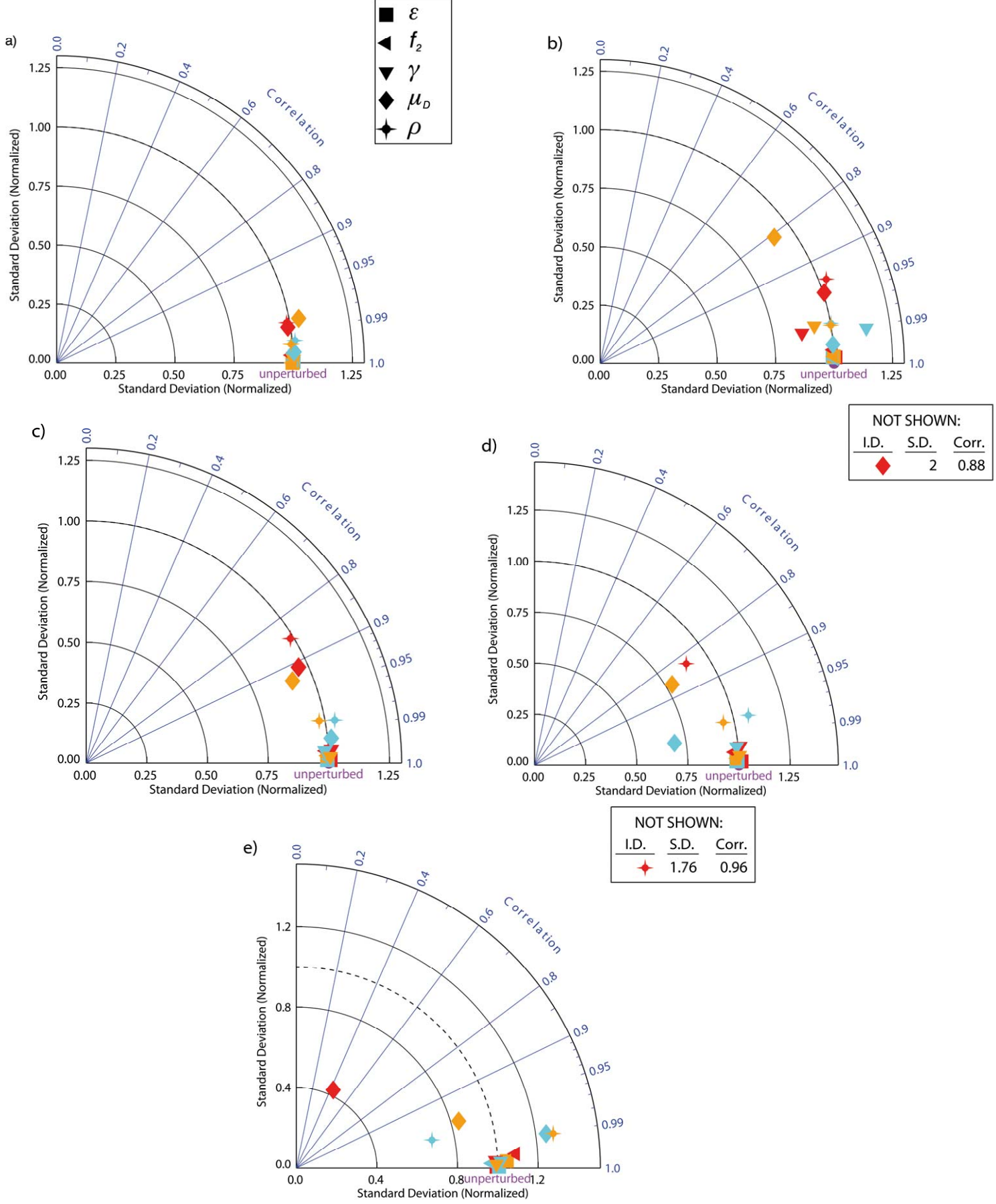

NOT SHOWN:
I.D. $\frac{\text { S.D. }}{1.76} \frac{\text { Corr. }}{0.96}$

Fig. 10. Model performance analyses using Taylor's diagrams showing results of sensitivity experiments (from mid-March to mid-July 1998, over the model domain) on surface Dissolved inorganic nitrogen (a), Phytoplankton (b), Zooplankton (c), Detritus (d) and Dissolved organic nitrogen (e) over the whole basin. The radial distance from the origin is proportional to the standard deviation of a pattern (normalised by the standard deviation of the unperturbed simulation). The green lines measure the distance from the reference point and indicate the RMS error (once any overall bias has been removed; see the mathematical expression in Sect. 2.2). The correlation between the two fields, the unperturbed simulation and the simulation with the modified parameter value is given by the azimuthal position of the test field. $\varepsilon, f_{2}, \gamma, \mu_{\mathrm{D}}$ and $\rho$ represent phytoplankton exudation rate, organic fraction of excretion, zooplankton excretion rate, hydrolysis rate of detritus and remineralisation rate, respectively (see Table 3). Parameters are modified one by one and their reference values are: divided by two $(-50 \%$ in orange), multiplied by two (+100\% in blue) and equal to a very small value, $10^{-4}(-100 \%$ in red). 
These sensitivity experiments showed that DON in the ecosystem model strongly depends on its main source: the hydrolysis. Other origins of DON have a weaker influence on other state variable concentrations in the model. As expected, the sink of DON, the remineralization loop between DON and $\mathrm{N}$, has a significant effect on all model state variables. This analysis confirmed that DON plays an important role in less productive regions with respect to high productive regions (not shown), in agreement with the study from Gunson et al. (1999). Indeed, they showed that detrital sinking and remineralization rates have no influence on surface chlorophyll concentrations at high latitudes and great influence on surface chlorophyll concentrations at low latitudes.

\section{Role of DON in sustaining primary production in the north Atlantic Ocean}

We will examine here the source and sink terms as well as advection/diffusion of the $\mathrm{N}$ and DON equations to assess the DON role in sustaining the primary production in the oligotrophic region. We have shown in the previous section the central role of dissolved organic nitrogen (DON) in the north Atlantic Ocean. We will now discuss the different nitrogen sources sustaining the primary production, especially the DON supply in the North Atlantic subtropical gyre. As examined by other studies (e.g. Mahaffey et al., 2004; Roussenov et al., 2006) based on modelling and/or in situ data, processes associated with DON dynamics could supply a part of the primary production in this oligotrophic gyre. Indeed, the lateral supply of DON from productive and upwelling zones might penetrate further into the subtropical gyre than does dissolved inorganic nitrogen, because the semi-labile pool of DON has a longer lifetime in the euphotic zone (Williams and Follows, 1998).

The biological sources of inorganic nutrient simulated by the NPZDDON model, zooplankton excretion and remineralisation of DON by bacteria, are first examined. Over the subtropical gyre in the north Atlantic Ocean for the year 1998, the supply from DON (Fig. 11a) largely dominates the source from zooplankton excretion (Fig. 11b) by an order of magnitude. Our results are in agreement with similar model studies as Huret et al. (2005) where ZOO to DIN flux represent $264510^{6} \mathrm{molN}$ and DON to DIN dominates with $1940010^{6}$ molN. In Dadou et al. (2004), ZOO to DIN fluxes are almost equal to DON to DIN fluxes. As mentioned in Salihoglu et al. (2008), large amounts of nutrient can be made available in the upper ocean by rapid cycling of dissolved organic matter released by a variety of processes including phytoplankton exudation, bacterial release, viral lysis, zooplankton excretion and grazing. Then, the role of locally generated nutrients for primary production through semilabile DON can be important (i.e. Salihoglu et al., 2008). The northern and southern borders of the subtropical gyre as well as the large Mauritanian upwelling represent areas with large supply of inorganic nutrient: $1.5-2 \mathrm{molN} \mathrm{m}^{-2} \mathrm{yr}^{-1}$ from remineralisation of $\mathrm{DON}$ and $0.2-0.3 \mathrm{molN} \mathrm{m}^{2} \mathrm{yr}^{-1}$ from zooplankton excretion (Fig. 11a and b). This general picture is consistent with the study from Williams and Follows (1998) and could be due to transport of DON from the enriched surrounding regions by the convergent Ekman transport over the subtropical gyre. This convergent transport can be decomposed in 3 main components: the offshore transport of nutrient rich waters from the continental margins toward the centre of the subtropical gyre, the outward transport induced by the mean eastward wind at the northern boundary of the subtropical gyre as well as the northward transport induced by the trade winds at the southern flank of the subtropical gyre. We now examine the DON and inorganic nutrient supplies by physical transport, especially the meridional advection in the coupled model (Fig. 11c and d). As expected, the northern flank of the subtropical gyre represents a mean southward meridional transport of DON around $-2.7 \mathrm{mmolN} \mathrm{m}^{-1} \mathrm{yr}^{-1}$ (around $23^{\circ} \mathrm{N}$ ) and the southern flank a northward meridional advection around $6.3 \mathrm{mmolN} \mathrm{m}^{-1} \mathrm{yr}^{-1}$ (around $11.3^{\circ} \mathrm{N}-$ Fig. $11 \mathrm{c}$ ).

The meridional transport of nitrate (Fig. 11d) differs from the transport of DON. The transport is higher than the transport of DON and it flows mainly southward south of $25^{\circ} \mathrm{N}$ and northward between $25^{\circ} \mathrm{N}$ and $30^{\circ} \mathrm{N}$.

To study the meridional supply of DON, the meridional transport of DON was zonally integrated over the basin from $71^{\circ} \mathrm{W}$ to the eastern boundary (Fig. 12). From the wind field used to force the coupled model, the Ekman meridional flux of DON has also been estimated (Fig. 12). Between $7^{\circ} \mathrm{N}$ and $20^{\circ} \mathrm{N}$, the total meridional DON transport is northward as well as the Ekman component. However, the total component is smaller than the Ekman contribution. At the opposite, between $22^{\circ} \mathrm{N}$ and $36^{\circ} \mathrm{N}$, the total southward DON transport has mainly a reverse direction as compared to the Ekman component. In between $\left(20^{\circ} \mathrm{N}-22^{\circ} \mathrm{N}\right)$, the total DON transport is close to zero. This area is associated with the lowest primary production value in the subtropical gyre. Other processes, as meridional current components, eddies, meanders and fronts, decrease the northward DON transport mainly driven by the Ekman dynamics. Furthermore, the difference between the Ekman transport and the total transport, reaching $+10.7 \mathrm{kmolN} \mathrm{s}^{-1}$ (Fig. 12), has a stronger influence north of $22^{\circ} \mathrm{N}$. Indeed, it induces a change in the transport direction. The meridional DON supply in the subtropical gyre of the north Atlantic Ocean can not be systematically explained only by the Ekman dynamics. Indeed, the southward total transport at the northern border of the subtropical gyre is mainly driven by other processes. Our estimates, using a realistic modelling approach, are in agreement with previous studies using simplified cycling and transport model for DON and in situ data. For example, Roussenov et al. (2006) found a $179 \mathrm{kmolN} \mathrm{s}^{-1}$ at $12^{\circ} \mathrm{N}$ of meridional flux of total DON. Assuming a $10 \%$ fraction of semi-labile DON in the total DON (as in Mahaffey et al., 2004), this estimation 

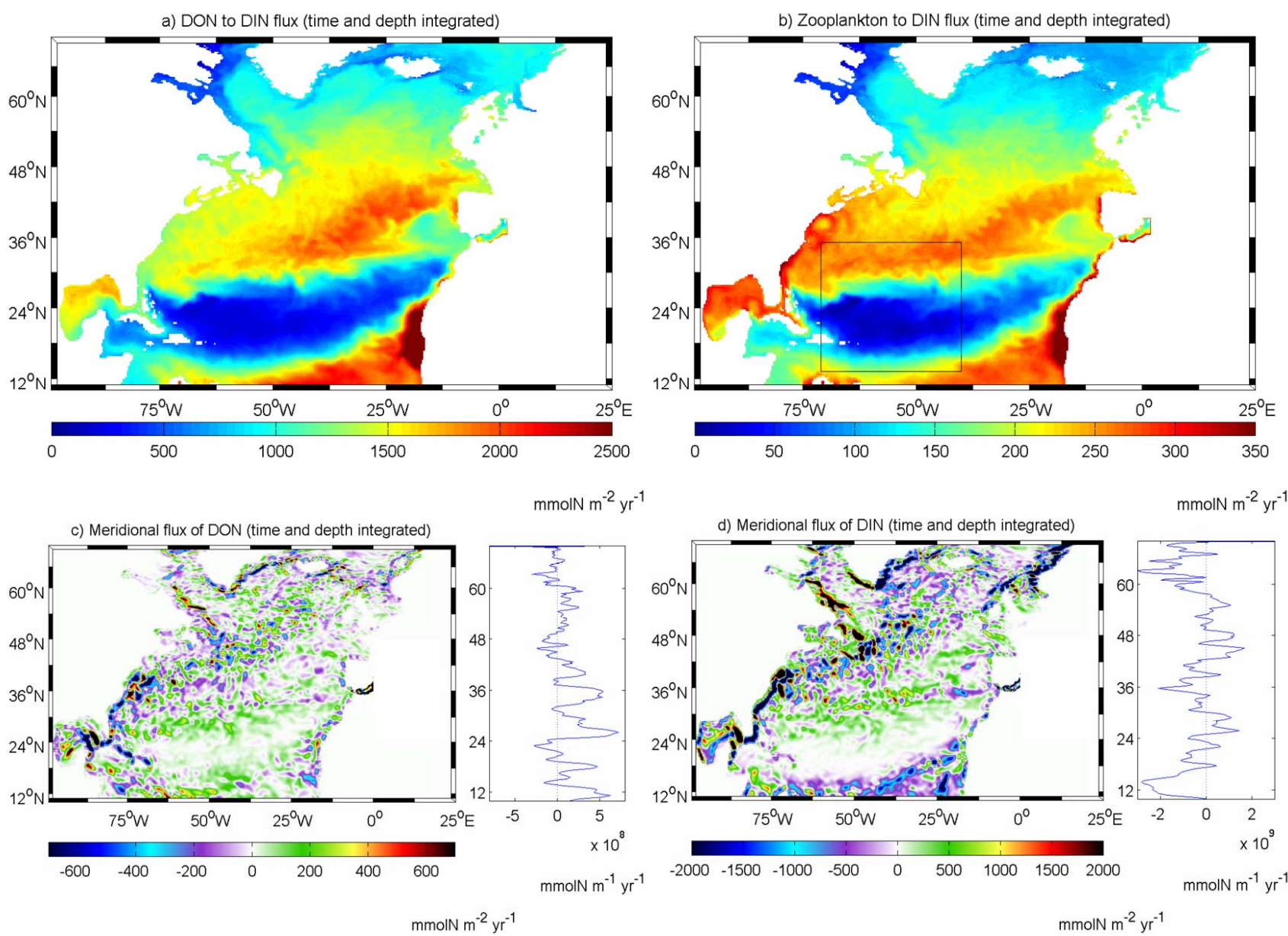

Fig. 11. Spatial distribution integrated over the first $112 \mathrm{~m}$ and over the year $1998 \mathrm{in} \mathrm{mmolN} \mathrm{m}{ }^{-2} \mathrm{yr}^{-1}$ of (a) remineralisation of DON (0-2500 mmolN m ${ }^{-2} \mathrm{yr}^{-1}$ ) (b) zooplankton excretion (0-350 mmolN m $\mathrm{yr}^{-1}$ ) (c) meridional advective flux of DON (-700$700 \mathrm{mmolN} \mathrm{m}^{-2} \mathrm{yr}^{-1}$ ) (d) meridional advective flux of DIN (-2000-2000 mmolN m$\left.{ }^{-2} \mathrm{yr}^{-1}\right)$. The black rectangle on panel (b) represents the region from $13^{\circ} \mathrm{N}$ to $35^{\circ} \mathrm{N}$ and from $71^{\circ} \mathrm{W}$ to $40^{\circ} \mathrm{W}$ where the budgets are estimated. The right panels associated to maps (c) and (d) are representing the corresponding zonally integrated fluxes over the basin.

$\left(17.9 \mathrm{kmolN} \mathrm{s}^{-1}\right)$ compares quite well with our meridional modelled transport of $18 \mathrm{kmolN} \mathrm{s}^{-1}$. Mahaffey et al. (2004) found an Ekman northward semi-labile DON flux equal to $0.5 \mathrm{mmolN} \mathrm{m} \mathrm{s}^{-1} \mathrm{~s}^{-1}$ along the AMT10 transect at $10^{\circ} \mathrm{N}$, $21.5^{\circ} \mathrm{W}$. This estimation is very similar to the value of $0.65 \mathrm{mmolN} \mathrm{m}^{-1} \mathrm{~s}^{-1}$ at the same location obtained from our simulations. Assuming the same approximation than in Mahaffey et al. (2004) (same value of meridional DON transport over a $4000-\mathrm{km}$ zonal band at $10^{\circ} \mathrm{N}$ ), we found a $2.6 \mathrm{kmolN} \mathrm{s}^{-1}$ for the meridional semi-labile DON transport. This value is comparable to the $2.0 \mathrm{kmolN} \mathrm{s}^{-1}$ value $\left(0.5 \mathrm{mmolN} \mathrm{m} \mathrm{m}^{-1} \mathrm{~s}^{-1} \times 4000 \mathrm{~km}\right)$ from Mahaffey et al. (2004). These estimations are much lower than the zonally integrated value $\left(19.4 \mathrm{kmolN} \mathrm{s}^{-1}\right)$ at $10^{\circ} \mathrm{N}$ (Fig. 12). The heterogeneous zonal distribution of the meridional DON transport represents an important factor to take into account for the estimation of the zonally integrated meridional DON flux.
Our analyses showed that the DON supply in the subtropical gyre is mainly driven by the meridional Ekman transport, south of $20^{\circ} \mathrm{N}$, as suggested in recent studies (Mahaffey et al., 2004; Roussenov et al., 2006). However, our study pointed out the contribution of other processes (meridional current components, eddies, meanders and fronts) mainly in the northern part of the subtropical gyre.

To identify the processes sustaining primary production and to compare the different sources-sinks of nitrate and DON, an upper water column budget for these two quantities was computed in the first $112 \mathrm{~m}$ depth over a given area in the subtropical gyre (between $13^{\circ}$ and $35^{\circ} \mathrm{N}$ and between $71^{\circ}$ and $40^{\circ} \mathrm{W}-$ Fig. 11b) for the year 1998 (Fig. 13). The primary production is in good agreement with other estimations (see Table 2) and it corresponds to $75610^{13} \mathrm{mmolN}$ over the budget area. This primary production is mainly sustained by biological nitrogen supply from zooplankton excretion and DON remineralisation 


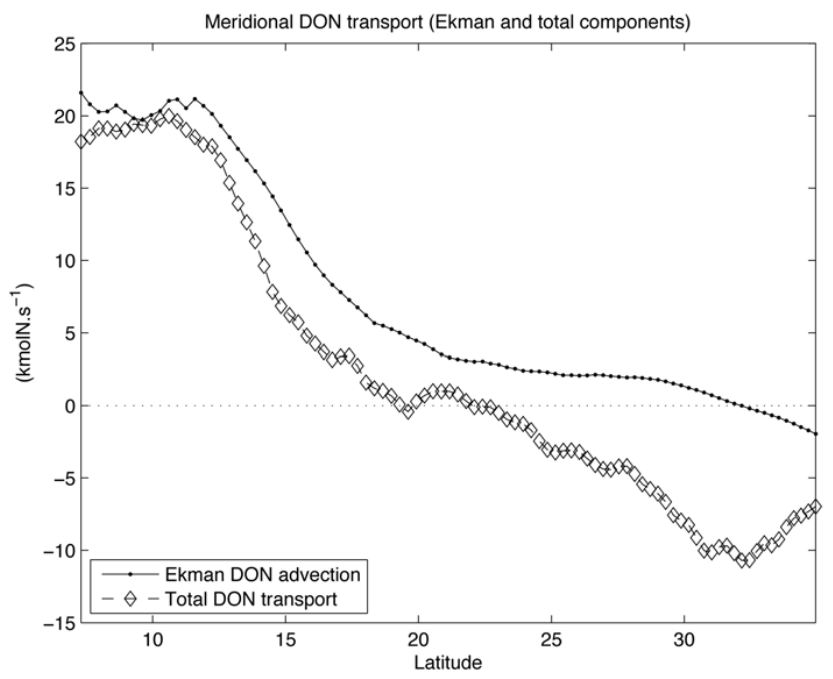

Fig. 12. Meridional transport of DON zonally integrated from $71^{\circ} \mathrm{W}$ to the eastern boundary (dashed line) and meridional Ekman transport of DON (solid line) in $\mathrm{kmolN} \mathrm{s}^{-1}$. The positive values represent a northward transport.

(99\%; $\left.75110^{13} \mathrm{mmolN}\right)$. The Dissolved Inorganic Nitrogen (DIN) necessary to sustain this primary production comes mainly from the DON pool. It represents $85 \%$ of the DIN biological sources. If we investigate further the origins of the DIN available for primary production, we can notice that the main source of the DON supply by advection is the meridional transport of DON $\left(80 \%, 27.710^{13} \mathrm{mmolN}\right)$. The other sources of DON come from the exudation of phytoplankton, organic excretion of zooplankton and hydrolysis of particulate organic nitrogen.

Following the biogeochemical fluxes in this region (Fig. 13), it appears clearly that the meridional advection of DON is an important source of DIN necessary to sustain primary production. However, the advection and diffusion of DIN also represent a small source of nitrogen $\left(17.310^{13} \mathrm{mmolN}\right)$ which could be much more important if it was not balanced by a loss of nitrogen by vertical advection.

The dissolved organic matter plays a key role in nitrogen, but also in phosphorus cycling. For example, at BATS (Salihoglu et al., 2008) and at HOT in the North Pacific subtropical gyre (Christian, 2005), the importance of the Dissolved Organic Phosphorus (DOP) has been demonstrated using modelling and in situ measurements. The DOP can sustain the level of primary production in these nitrogen and phosphorus limited regions. Indeed, studies in the last ten years have highlighted the role of phosphorus as a limiting nutrient in the Atlantic Ocean (Wu et al., 2000; Lipschultz et al., 2002; Ammerman et al., 2003; Lomas et al., 2004). Furthermore, in the present study, a fixed $\mathrm{C} / \mathrm{N}$ ratio was used to estimate the C-based primary production. However, limiting nutrients depend on $\mathrm{C} / \mathrm{N} / \mathrm{P}$ ratio, which can be different of
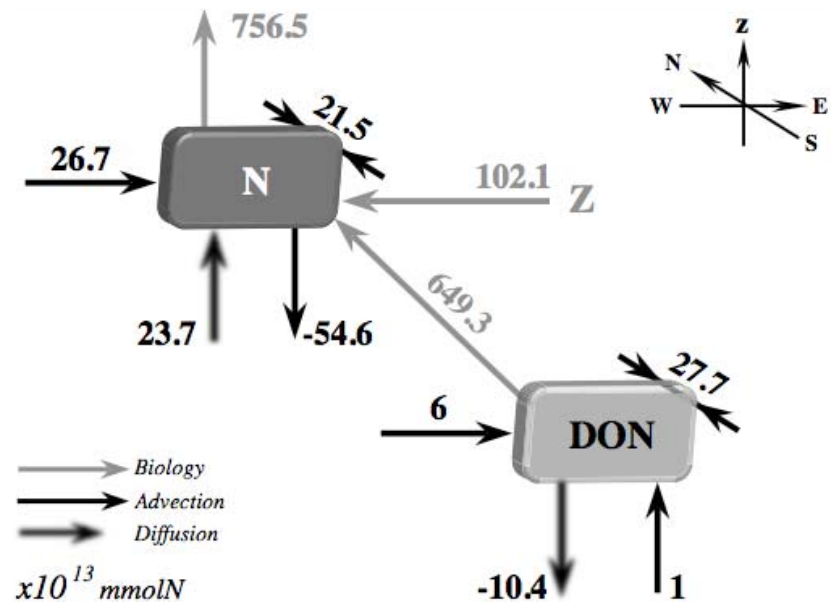

Fig. 13. Budget of sources and sinks (advective, diffusive and biogeochemical) of dissolved inorganic nitrogen and dissolved organic nitrogen over a given area (between $13^{\circ} \mathrm{N}$ and $35^{\circ} \mathrm{N}$ and between $71^{\circ} \mathrm{W}$ and $40^{\circ} \mathrm{W}$ ) for the first $112 \mathrm{~m}$ during the year 1998.

the canonical Redfield ratio. For example, Christian (2005) and Salihoglu et al. (2008) obtained a better estimation of the primary production using variable intracellular $\mathrm{C} / \mathrm{N} / \mathrm{P}$ for phytoplankton. Indeed, the decrease of the primary production with depth is well reproduced in agreement with in situ data.

\section{Conclusions}

DON represents an important source of DIN in the subtropical gyre of the north Atlantic Ocean. The supply of DON by physical processes in this gyre is dominated by meridional transports. Indeed, south of $20^{\circ} \mathrm{N}$, a northern transport mainly due to the Ekman component sustains the primary production in the oligotrophic gyre. This input is increased by a southward transport north of $22^{\circ} \mathrm{N}$ associated with nonEkman dynamics. Our estimate of the mean value of the meridional DON transport, $0.039 \mathrm{molN} \mathrm{m}^{-2} \mathrm{yr}^{-1}$, confirms the importance of this process as compared to other possible mechanisms, ranging from 0.01 to $0.24 \mathrm{molN} \mathrm{m}^{-2} \mathrm{yr}^{-1}$, to fuel primary production in the north Atlantic subtropical gyre. The meridional transport of dissolved organic matter can introduce a similar amount of nutrient as the $\mathrm{N}_{2}$-fixation process. The dissolved organic nitrogen and phosphorus, and the variable $\mathrm{C} / \mathrm{N} / \mathrm{P}$ for phytoplankton should be implemented in a three-dimensional view of the north Atlantic Ocean. To fully understand the processes controlling primary and export productions as well as the climate change impact on the ocean, the phosphorus cycle should be considered as well as other cycles (silicon and iron). 


\section{Appendix A}

\section{Sources and sinks of the biogeochemical model}

The tracer concentrations - Phytoplankton (P), Zooplankton (Z), Dissolved Inorganic Nitrogen (N), Detritus (D) and Dissolved Organic Nitrogen (DON) - follow an advectivediffusive equation plus a source-minus-sink (SMS) term of exchange between different tracers. The SMS terms for each of the biological tracer in nitrogen units $\left(\mathrm{mmolN} \mathrm{m}^{-3}\right)$ are:

$$
\begin{aligned}
& \operatorname{SMS}(\mathrm{N})=\rho \mathrm{DON}+\left(1-f_{2}\right) \gamma \mathrm{Z}-\mathrm{J}(z, t, \mathrm{~N}) \mathrm{P} \\
& \operatorname{SMS}(\mathrm{P})=(1-\varepsilon) \mathrm{J}(z, t, \mathrm{~N}) \mathrm{P}-\mu_{\mathrm{P}} \mathrm{P}-\mathrm{G}(\mathrm{P}) \mathrm{Z} \\
& \operatorname{SMS}(\mathrm{Z})=f_{1} \mathrm{G}(\mathrm{P}) \mathrm{Z}-\gamma \mathrm{Z}-\mu_{\mathrm{Z}} \mathrm{Z}^{2} \\
& \operatorname{SMS}(\mathrm{D})=\left(1-f_{1}\right) \mathrm{G}(\mathrm{P}) \mathrm{Z}+\mu_{\mathrm{P}} \mathrm{P}+\mu_{\mathrm{Z}} \mathrm{Z}^{2}-\mu_{\mathrm{D}} \mathrm{D}-w_{S} \frac{\partial \mathrm{D}}{\partial z} \\
& \operatorname{SMS}(\mathrm{DON})=\varepsilon \mathrm{J}(z, t, \mathrm{~N}) \mathrm{P}+f_{2} \gamma \mathrm{Z}+\mu_{\mathrm{D}} \mathrm{D}-\rho \mathrm{DON}
\end{aligned}
$$

\begin{tabular}{|c|c|}
\hline$\alpha$ & Initial slope of P-I curve \\
\hline$a, b, c$ & $\begin{array}{l}\text { Maximum phytoplankton growth rate } \\
\text { parameters }\end{array}$ \\
\hline$K_{\mathrm{N}}$ & $\begin{array}{l}\text { Half saturation concentration for nutrient } \\
\text { uptake }\end{array}$ \\
\hline$\mu_{\mathrm{P}}$ & Phytoplankton mortality rate \\
\hline$\varepsilon$ & Phytoplankton exudation rate \\
\hline$f_{1}$ & Assimilation efficiency of zooplankton \\
\hline$g$ & Maximum zooplankton grazing rate \\
\hline$p$ & Zooplankton capture rate \\
\hline$\mu_{\mathrm{Z}}$ & (Quadratic) zooplankton mortality \\
\hline$\gamma$ & Zooplankton excretion rate \\
\hline$f_{2}$ & Organic fraction of excretion \\
\hline$\mu_{\mathrm{D}}$ & Hydrolysis rate of detritus \\
\hline$w_{s}$ & Sinking velocity \\
\hline$\rho$ & Remineralization rate \\
\hline
\end{tabular}

The flux terms (identified in the Notation) are given by:

$$
\begin{aligned}
& \mathrm{J}(z, t, \mathrm{~N})=\min \left(\overline{\mathrm{J}}(z, t), \mathrm{J}_{\mathrm{max}} \mathrm{L}_{\mathrm{NO}_{3}}\right) \\
& \mathrm{J}_{\max }=a b^{c T} \\
& \mathrm{~L}_{\mathrm{NO}_{3}}=\frac{\mathrm{N}}{\mathrm{N}+K_{\mathrm{N}}} \\
& \overline{\mathrm{J}}(z, t)=\frac{1}{\tau_{24 h}} \int_{0}^{24 h} \frac{1}{z_{k}-z_{k-1}} \int_{z_{k-1}}^{z_{k}} \mathrm{~J}\left(z, t^{\prime}\right) d z d t^{\prime} \\
& \mathrm{J}\left(z, t^{\prime}\right)=\frac{\mathrm{J}_{\max } \alpha I\left(z, t^{\prime}\right)}{\left(\mathrm{J}_{\max }^{2}+\alpha^{2} I\left(z, t^{\prime}\right)^{2}\right)^{1 / 2}} \\
& \mathrm{G}(\mathrm{P})=\frac{g p \mathrm{P}^{2}}{g+p \mathrm{P}^{2}}
\end{aligned}
$$

\section{Notation:}

$T \quad$ Temperature (modelled state variable)

$\mathrm{N} \quad$ Concentration of the dissolved inorganic nitrogen $\left(\mathrm{mmolN} \mathrm{m}^{-3}\right)$, model state variable

$\mathrm{P} \quad$ Concentration of phytoplankton $\left(\mathrm{mmolN} \mathrm{m}^{-3}\right)$, model state variable

$\mathrm{Z} \quad$ Concentration of zooplankton $\left(\mathrm{mmolN} \mathrm{m}^{-3}\right)$, model state variable

D Concentration of detritus $\left(\mathrm{mmolN} \mathrm{m}^{-3}\right)$, model state variable

DON Concentration of dissolved organic nitrogen $\left(\mathrm{mmolN} \mathrm{m}^{-3}\right)$, model state variable

I Local light intensity

Biological parameters values are given in Table 1.

Acknowledgements. Financial support for this work was provided by the GMMC (Groupe Mission MERCATOR/CORIOLIS) to I. Dadou and V. Garçon at LEGOS (Toulouse, France). The physical model was provided by MERCATOR (http://www.mercator-ocean.fr). The calculations were conducted with the support of IDRIS/CNRS. The work was funded by CNES and IFREMER through a PhD fellowship, by the University Paul Sabatier through a postdoctoral fellowship and by the European Commission through a Marie-Curie postdoctoral fellowship (MEIF-CT-2006-039180). We are grateful to the AMT project (Carol Robinson) for providing their data and Claire Mahaffey for useful discussions. Ocean color data were produced by the SeaWiFS project at GSFC and obtained from the DAAC. We acknowledge Markus Schartau and an anonymous reviewer for constructive feedbacks.

Edited by: J. Middelburg

\section{References}

Aiken, J. and Bale, A. J.: An introduction to the Atlantic Meridional Transect (AMT) programme, Prog. Oceanogr., 45, 251256, 2000.

Ammerman, J. W., Hood, R. R., Case, D. A., and Cotner, J. B.: Phosphorus deficiency in the Atlantic: An emerging paradigm in oceanography, EOS, 84, 165-170, 2003.

Antoine, D. and Morel, A.: Ocean Primary Production, 2: Estimation at global scale from satellite (Coastal Zone Color Scanner) chlorophyll, Global Biogeochem. Cy., 10, 57-69, 1996.

Barnier, B., Miranda, A., Crosnier, L., Molines, J.-M., Tréguier A.-M., and Jouzeau, A.: Rapport scientifique et technique 1999, $\mathrm{N}^{\circ}$ CLIPPER-R3-2000, LPO, Brest, 2000.

Barnier, B., Madec, G., Penduff, T., Molines, J.-M., Tréguier, A.M., Le Sommer, J., Beckmann, A., Biastoch, A., Böning, C., Dengg, J., Derval, C., Durand, E., Gulev, S., Remy, E., Talandier, C., Theetten, S., Maltrud, M., McClean, J., and De Cuevas, B. Impact of partial steps and momentum advection schemes in a global ocean circulation model at eddy-permitting resolution, Ocean Dynam., 56, 543-567, 2006.

Behrenfeld, M. J., and Falkowski, P.: Photosynthetic rates derived from satellite-based chlorophyll concentration, Limnol. Oceanogr., 42, 1-20, 1997. 
Berline, L., Brankart, J. M., Brasseur, P., Ourmières, Y., and Verron, J.: Improving the physics of a coupled physical-biogeochemical model of the North Atlantic through data assimilation: Impact on the ecosystem, J. Marine Syst., 64(1-4), 153-172, 2007.

Blanke, B. and Delecluse, P.: Variability of the tropical Atlantic ocean simulated by a general circulation model with two different mixed-layer physics, J. Phys. Oceanogr., 23, 1363-1388, 1993.

Carr, M. E., Friedrichs, M. A. M., Schmeltz, M., et al.: A comparison of global estimates of marine primary production from ocean color, Deep-Sea Res. Pt. II, 53(5-7), 741-770, 2006.

Carlson, C. A. and Ducklow, H. W.: Dissolved organic carbon in the upper ocean of the central equatorial Pacific Ocean, 1992: daily and fine-scale vertical variations, Deep-Sea Res. Pt. II, 42(2-3), 639-656, 1995.

Charria, G.: Influence of Rossby waves on the biogeochemical system in the North Atlantic Ocean: Use of ocean colour remotely sensed data and of a coupled physical/biogeochemical model, PhD Thesis, University Paul Sabatier, Toulouse, France, 339 pp., 2005.

Christian, J. R.: Biogeochemical cycling in the oligotrophic ocean: Redfield and non-Redfield models, Limmol. Oceanogr., 50(2), 646-657, 2005.

Conkright, M., O’Brien, T., Levitus, S., Boyer, T. P., Antonov, J., and Stephens, C.: World Ocean Atlas 1998, NOAA Atlas NESDIS 36, US Government Printing Office, Washington, D. C., 245 pp., 1998.

Dadou, I., Evans, G., and Garçon, V.: Using JGOFS in situ and ocean color data to compare biogeochemical models and estimate their parameters in the subtropical North Atlantic Ocean, J. Mar. Res., 62, 565-594, 2004.

Drillet, Y., Bourdalle-Badie, R., Siefridt, L., and Le Provost, C.: Meddies in the Mercator North Atlantic and Mediterranean sea eddy resolving model, J. Geophys. Res., 110, C03016, doi:10.1029/2003JC002170, 2005.

Duce, R. A., LaRoche, J., Altieri, K., Arrigo, K. R., Baker, A. R., Capone, D. G., Cornell, S., Dentener, F., Galloway, J., Ganeshram, R. S., Geider, R. J., Jickells, T., Kuypers, M. M., Langlois, R., Liss, P. S., Liu, S. M., Middelburg, J. J., Moore, C. M., Nickovic, S., Oschlies, A., Pedersen, T., Prospero, J., Schlitzer, R., Seitzinger, S., Sorensen, L. L., Uematsu, M., Ulloa, O., Voss, M., Ward, B., and Zamora, L.: Impacts of Atmospheric Anthropogenic Nitrogen on the Open Ocean, Science, 320, 893 897, 2008.

Ducklow, H. W.: Biogeochemical Provinces: Towards a JGOFS Synthesis, in: Ocean Biogeochemistry, edited by: Fasham, M. J. R., Springer, 3-17, 2003.

Emerson, S., Quay, P., Karl, D., Winn, C., Tupas, L., and Landry, M.: Experimental determination of the organic carbon flux from open-ocean surface waters, Nature, 389(6654), 951-954, 1997.

Estubier, A. and Lévy, M.: Quel schéma numérique pour le transport d'organismes biologiques par la circulation océanique? Note Technique du Pôle de modélisation, Institut Pierre-Simon Laplace (IPSL), 81 pp., 2000.

Etienne, H. and Benkiran, M.: Multivariate assimilation in MERCATOR project: New statistical parameters from forecast error estimation, J. Marine Syst., 65, 430-449, 2007.

Gruber, N. and Sarmiento, J. L.: Global patterns of marine nitrogen fixation and denitrification, Global Biogeochem. Cy., 11(2),
235-266, 1997.

Gunson, J., Oschlies, A., and Garçon, V.: Sensitivity of ecosystem parameters to simulated satellite ocean colour data using a coupled physical-biological model of the North Atlantic, J. Mar. Res., 57, 613-639, 1999.

Hansell, D. A., Ducklow, H. W., Macdonald, A. M., and Baringer, M. O.: Metabolic poise in the North Atlantic Ocean diagnosed from organic matter transports, Limnol. Oceanogr., 49(4), 10841094, 2004.

Huret, M., Dadou, I., Dumas, F., Lazure, P., and Garçon, V.: Coupling physical and biogeochemical processes in the Río de la Plata plume, Cont. Shelf Res., 25(5-6), 629-653, 2005.

Kähler, P. and Koeve, W.: Marine dissolved organic matter: can its C:N ratio explain carbon overconsumption?, Deep-Sea Res. Pt. I, 48, 49-62, 2001.

Kirchman, D. L., Lancelot, C., Fasham, M., Legendre, L., Radach, G., and Scott, M.: Dissolved organic matter in biogeochemical models in the ocean, in: Towards a model of ocean biogeochemical processes, Springer Verlag, Berlin, 209-225, 1993.

Knapp, A. N., Sigman, D. M., and Lipschultz, F.: N isotopic composition of dissolved organic nitrogen and nitrate at the Bermuda Atlantic Time-series Study site, Global Biogeochem. Cy., 19, GB1018, doi:10.1029/2004GB002320, 2005.

Lipschultz, F., Bates, N., Carlson, C., and Hansell, D.: New production in the Sargasso Sea: History and current status, Global Biogeochem. Cy., 16, 1-16, 2002.

Lomas, M. W. and Bates, N. R.: Potential controls on interannual partitioning of organic carbon during the winter/spring phytoplankton bloom at the Bermuda Atlantic Time-series (BATS) site, Deep-Sea Res. Pt. I, 51, 1619-1636, 2004.

Longhurst, A. R., Sathyendranath, S., Platt, T., and Caverhill, C.: An estimate of global primary production in the ocean from satellite radiometer data, J. Plankton Res., 17, 1245-1271, 1995.

Longhurst, A. R.: Ecological Geography of the Sea, Academic Press, 542 pp., 1998.

McClain, C. R., Signorini, S. R., and Christian, J. R.: Subtropical gyre variability observed by ocean-color satellites, Deep-Sea Res. Pt. II, 51, 281-301, 2004.

McGillicuddy, D. J. and Robinson, A. R.: Eddy-induced nutrient supply and new production in the Sargasso Sea, Deep-Sea Res. Pt. I, 44(8), 1427-1450, 1997.

Madec, G., Delecluse, P., Imbard, M., and Levy, C.: OPA 8.1 Ocean General Circulation Model reference manual, Note Technique du Pôle de modélisation, Institut Pierre-Simon Laplace (IPSL), France, 91 pp., 1999.

Mahaffey, C., Williams, R. G., Wolff, G. A., and Anderson, W.: Physical supply of nitrogen to phytoplankton in the Atlantic Ocean, Global Biogeochem. Cy., 18, GB1034, doi:10.1029/2003GB002129, 2004.

Mélin, F. : Potentiel de la télédétection pour l'analyse des propriétés optiques du système océan-atmosphère et application à l'estimation de la photosynthèse phytoplanctonique, $\mathrm{PhD}$ Thesis, University Paul Sabatier, Toulouse, 514 pp., 2003.

Morel, A., Antoine, D., Babin, M., and Dandonneau, Y.: Measured and modeled primary production in the northeast Atlantic (EUMELI JGOFS program): The impact of natural variations in photosynthetic parameters on model predictive skill, Deep-Sea Res. Pt. I, 43(8), 1273-1304, 1996.

O'Reilly, J. E., Maritorena, S., Siegel, D. A., et al.: Ocean Color 
Chlorophyll a Algorithms for SeaWiFS, OC2, and OC4: Version 4, SeaWiFS Postlaunch Calibration and Validation Analyses, Part 3, NASA Technical Memorandum 206892, 11, 9-23, 2000.

Oschlies, A.: Can eddies make ocean deserts bloom?, Global Biogeochem. Cy., 16(4), 1106, doi:10.1029/2001GB001830, 2002.

Oschlies, A. and Garçon, V.: An eddy-permitting coupled physicalbiological model of the North Atlantic. 1. Sensitivity to advection numerics and mixed layer physics, Global Biogeochem. Cy., 13(1), 135-160, 1999.

Palter, J. B., Lozier, M. S., and Barber, R. T.: The effect of advection on the nutrient reservoir in the North Atlantic subtropical gyre, Nature, 437, 687-692, 2005.

Pujo-Pay, M. and Raimbault, P.: Observations chimiques et biomasse dans l'océan Atlantique tropical Nord, campagnes EUMELI, Résultats des measures, Rapport Centre Océanologique de Marseille, France, 65 pp., 1994.

Pujo-Pay, M. : L'azote et le phosphore en milieu marin, importance des formes organiques en milieu océanique du large, $\mathrm{PhD}$ Thesis, Université de la Méditerranée, Marseille, France, 164 pp., 1995.

Reynaud, T., Legrand, P., Mercier, H., and Barnier, B.: A new analysis of hydrographic data in the Atlantic and its application to an inverse modelling study, International WOCE Newsletters, 32, 29-31, 1998.

Reynolds, R. W. and Smith, T.: Improved global sea surface temperature analysis using optimum interpolation, J. Climate, 7, 929948, 1994.

Roussenov, V., Williams, R. G., Mahaffey, C., and Wolff, G. A.: Does the transport of dissolved organic nutrients affect production in the Atlantic Ocean?, Global Biogeochem. Cy., 20, GB3002, doi:10.1029/2005GB002510, 2006.

Sakshaug, E., Andresen, K., and Kiefer, D.: A steady state description of growth and light absorption in the marine planktonic diatom Skeleronema costatum, Limnol. Oceanogr., 34(1), 198$205,1989$.
Salihoglu, B., Garçon, V., Oschlies, A., and Lomas, M. W.: Influence of nutrient utilization and remineralization stoichiometry on phytoplankton species and carbon export: a modeling study at BATS, Deep-Sea Res. Pt. I, 55, 73-107, 2008.

Sarmiento, J. L., Slater, R. D., Fasham, M. J. R., Ducklow, H. W., Toggweiler, J. R., and Evans, G. T.: A Seasonal ThreeDimensional Ecosystem Model of Nitrogen Cycling in the North Atlantic Euphotic Zone, Global Biogeochem. Cy., 7(2), 417450, 1993.

Siegel, D. A., McGillicuddy Jr., D. J. , and Fields, E. A.: Mesoscale eddies, satellite altimetry, and new production in the Sargasso Sea, J. Geophys. Res., 104(C6), 13 359-13379, 1999.

Steinberg, D. K., Carlson, C. A., Bates, N. R., Johnson, R. J., Michaels, A. F., and Knap, A. H.: Overview of the US JGOFS Bermuda Atlantic Time-series Study (BATS): a decade-scale look at ocean biology and biogeochemistry, Deep-Sea Res. Pt. II, 48, 1405-1447, 2001.

Taylor, K. E.: Summarizing multiple aspects of model performance in a single diagram, J. Geophys. Res., 106(D7), 7183-7192, 2001.

Tréguier, A. M., Barnier, B., de Miranda, A., Molines, J.-M., Grima, N., Imbard, M., Madec, G., Messager, C., and Michel, S.: An eddy permitting model of the Atlantic circulation: evaluating open boundary conditions, J. Geophys. Res., 106, 22 115$22129,2001$.

Vidal, M., Duarte, C. M., and Agusti, S.: Dissolved organic nitrogen and phosphorus pools and fluxes in the central Atlantic Ocean, Limnol. Oceanogr., 44(1), 106-115, 1999.

Williams, G. G. and Follows, M. J.: The Ekman transfer of nutrients and maintenance of new production over the North Atlantic, Deep-Sea Res. Pt. I, 45(2-3), 461-489, 1998.

Wu, J., Sunda, W., Boyle, E. A., and Karl, D. M.: Phosphate depletion in the western North Atlantic Ocean, Science, 289, 759-762, 2000 . 